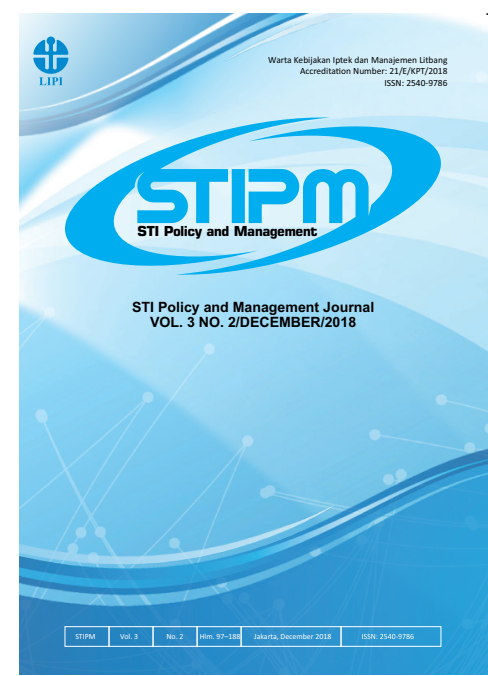

Journal of STI Policy and Management

Publication details, including instructions for authors and subscription information: http://www.stipmjournal.org/

\title{
Internal Innovation Capacity and External Linkages in Firms of Asean Economies Focusing on Endogeneity
}

\section{Masaru Ogawa ${ }^{1}$, Yasuhi Ueki ${ }^{2}$, Hiroki Idota ${ }^{3}$, Teruyuki Bunno ${ }^{4}$,} and Masatsugu Tsuji ${ }^{5}$

${ }^{1}$ Faculty of Business Administration, Kobe Gakuin University ${ }^{2} I D E / J E T R O$

${ }^{3}$ Faculty of Economics, Kindai University

${ }^{4}$ Faculty of Business Administration, Kindai University

${ }^{5}$ Facuty of Economics, Kobe International University

Version of record first published: 15 December 2018

To cite this article: Ogawa, S., Ueki, Y., Idota, H., Bunno, T., and T. Masatsugu. (2018). Internal Innovation Capacity and External Linkages in FIRMS of ASEAN Economies Focusing on Endogeneity. Journal of STI Policy and Management, 3(2), 97-117

To link to this article: http://dx.doi.org/10.14203/STIPM.2017.135

ISSN 2540-9786 (Print); ISSN 2502-5996 (online)

Accreditation Number: 21/E/KPT/2018

Full terms and conditions of use: https://creativecommons.org/licenses/by-nc-sa/4.0/

You are free to:

- Share : copy and redistribute the material in any medium or format

- Adapt : remix, transform, and build upon the material

- The licensor cannot revoke these freedoms as long as you follow the license terms.

Under the following terms:

Attribution - You must give appropriate credit, provide a link to the license, and indicate if changes were made. You may do so in any reasonable manner, but not in any way that suggests the licensor endorses you or your use.

NonCommercial - You may not use the material for commercial purposes.

ShareAlike - If you remix, transform, or build upon the material, you must distribute your contributions under the same license as the original.

No additional restrictions - You may not apply legal terms or technological measures that legally restrict others from doing anything the license permits.

Notices:

- You do not have to comply with the license for elements of the material in the public domain or where your use is permitted by an applicable exception or limitation.

- No warranties are given. The license may not give you all of the permissions necessary for your intended use. For example, other rights such as publicity, privacy, or moral rights may limit how you use the material.

- If you copy the dataset merely to extract the uncopyrightable data elements would not need permission to do so. However, if you republish the full dataset or using the copyrightable data layers require a permission from PAPPIPTEK-LIPI. 


\title{
JOURNAL OF SCIENCE, TECHNOLOGY, AND INNOVATION POLICY AND MANAGEMENT (STIPM JOURNAL), Volume 03, Number 02, December 2018
}

\author{
FOREWORD by EDITOR-in-CHIEF
}

We are very pleased to inform the readers that Journal of Science, Technology, \& Innovation Policy and Management (STIPM Journal) Vol. 3, No. 2, December 2018 is now ready for public reading and views. STIPM Journal is an online research journal, managed by the Center for Science and Technology Development Studies, Indonesian Institute of Sciences (PAPPIPTEK-LIPI).

This journal in fact provides scientific information needed mostly by research scholars. As a peer reviewed journal, STIPM provides free public access to all articles. Two issues, namely scientific review on variables and dimensions of national innovation capability, as well as research findings on development and adoption of science, technology, and innovation policy and management from Japan and Indonesia, are presented.

The first article "Internal Innovation Capacity and External Lingkages in Firms of ASEAN Economies Focusing on Endogeneity" is composed by Masaru OGAWA et al. This research article examines the role of internal innovation capacity, which includes technological level, organizational learning, and human resources on innovation. The second research article entitled "Drivers of Innovation without Formal R\&D: Selected Cases of Indonesian Firms". This article is presented by Erman AMINULLAH et al. The objective of this research study is to obtain a deep understanding about "why and how" firms engaging in innovation without formal $\mathrm{R} \& \mathrm{D}$, through deep analysis of three cases of firms in machinery and food processing sectors.

Uruqul Nadhif DZAKIY presents an article entitled "Technology-based Start-up: A Formula to become Sustainable Company in Indonesia, Lessons-learned from UAVINDO Nusantara". UAVINDO is a sample of technology-based company in Indonesia which has the characteristics of sustainable company. The fourth article entitled "Development Strategy of National Microsatellite Industry: Case Study of Indonesia", is presented by Chusnul Tri JUDIANTO et al. By applying SWOT and Quantitative Strategic Planning Matrix (QSPM) methods, this research identifies and analyzes the alternative strategy from external and internal factors and selects the appropriate and precise strategy for developing the microsatellite industry.

Hadi KARDOYO et al. present an article entitled "Knowledge Accumulation-based Entrepreneurship in the Creative Industry: A Case Study of Woodwork Firms in Indonesia." This article describes the activities of knowledge-entrepreneurship in four wood craft firms, namely Radio Magno, Stranough Guitar Technologi, Secco Guitar, and Matoa Watch, and also shows some lessons from Knowledge Intensive Entrepreneur (KIE). The last article composed by Ahmad Dading GUNADI et al. presents a "Scientifc Review on National Capability Variables and Dimensions." This paper analyses the dimensions and variables of National Innovation Capability through a system approach that includes three sub-systems, namely Input, Process, and Output. 
After indexing by Google Scholar, ISJD and IPI, STIPM Journal is now indexed with DOAJ, BASE, and OCLC World Cat. This has made the journal's dissemination broader. We would like to express our immense gratitude to our international editorial board members, reviewers and authors for their contribution to this issue. We hope this publication will prove useful for readers and could contribute to the enhancement of science, technology and innovation innitiatives. We expect that STIPM will always provide a higher scientific platform for authors and readers, with a comprehensive overview of the most recent STI Policy and Management research and development at the national, regional dan international levels. Finally, wishing you a HAPPY NEW YEAR 2019. May your New Year be filled with great achievements, good health, peace, happines, and joy.

Jakarta, December 2018

Editor-In-Chief 



\section{JOURNAL OF STI POLICY AND MANAGEMENT}

Volume 3, Number 2, December 2018

\section{LIST OF CONTENTS}

Internal Innovation Capacity and External Linkages in FIRMS of ASEAN Economies Focusing on Endogeneity

Masaru Ogawa, Yasuhi Ueki, Hiroki Idota, Teruyuki Bunno, and Masatsugu Tsuji

Drivers of Innovation Without Formal R\&D: Selected cases of Indonesian firms

Erman Aminullah, Trina Fizzanty, Qinan M.B. Soesanto.

Technology-Based Startup: A Formula to Become Sustainable Company in Indonesia a Case Study from UAVINDO Nusantara

Uruqul Nadhif Dzakiy

Development Strategy of National Microsatellite Industry: Case Study of Indonesia

Chusnul Tri Judianto, Harianto, and Agus Maulana

Knowledge Accumulation-Based Entrepreneurship (KABE) in the Creative Industry: A Case Study of Woodwork Firms in Indonesia

Hadi Kardoyo, Setiowiji Handoyo, and Anugerah Yuka Asmara $161-173$

National Innovation Capability Variables and Dimensions

Ahmad Dading Gunadi, Yandra Arkeman, Rizal Syarief Siaiful Nazli, Teguh Rahardjo, and Aulijati Wachjudiningsih. 


\title{
is STI POLICY AND MANAGEMENT

\section{Internal Innovation Capacity and External Linkages in FIRMS of ASEAN Economies Focusing on Endogeneity}

\author{
Masaru Ogawa $^{1}$, Yasuhi Ueki ${ }^{2}$, Hiroki Idota ${ }^{3}$, Teruyuki Bunno ${ }^{4}$, and Masatsugu Tsuji ${ }^{5}$ \\ ${ }^{1}$ Faculty of Business Administration, Kobe Gakuin University \\ 1-1-3, Minatojima, Chuo-ku, Kobe 650-8586, Japan \\ ${ }^{2}$ IDE/JETRO \\ 3-2-2, Wakaba, Mihama-ku, Chiba-shi, Chiba \\ 261-8545, Japan \\ ${ }^{3}$ Faculty of Economics, Kindai University \\ 3-4-1, Kowakae, Higashi-osaka, Japan \\ ${ }^{4}$ Faculty of Business Administration, Kindai University \\ 3-4-1, Kowakae, Higashi-osaka, Japan \\ ${ }^{5}$ Facuty of Economics, Kobe International University \\ 9-1-6 Koyocho-naka, Higashinada-ku, Kobe 658-0032, Japan
}

\begin{tabular}{|c|c|}
\hline ARTICLE INFO & ABSTRACT \\
\hline Article History: & \multirow{12}{*}{$\begin{array}{l}\text { Based on data of firms' survey in four ASEAN economies, this paper } \\
\text { examines the role of internal innovation capacity, which includes } \\
\text { technological level, organizational learning, and human resources on } \\
\text { innovation. An index of internal capacity using Analytical Hierarchy } \\
\text { Process (AHP) was constructed to make the concept of internal } \\
\text { innovation capacity more tractable for statistical analysis. By using } \\
\text { this index, this paper attempts to examine how the internal capacity } \\
\text { of firms is enhanced by external linkages such as with Multinational } \\
\text { Corporations (MNCs), universities, and public organizations. In } \\
\text { particular, this study analyzes the endogeneity problem, which } \\
\text { clarifies the causality between innovation and its promoting factors. } \\
\text { In so doing, the instrumental variable method was employed, and as } \\
\text { a result, external linkages enhanced internal innovation capacity, and } \\
\text { internal innovation capability promoted innovation, while external } \\
\text { linkages indirectly enhanced innovation. }\end{array}$} \\
\hline Received : 07 May 2018 & \\
\hline Revised : 22 November 2018 & \\
\hline Accepted : 22 November 2018 & \\
\hline Available online : 15 December 2018 & \\
\hline Keywords: & \\
\hline MNCs & \\
\hline AHP & \\
\hline Causality & \\
\hline Endogeneity & \\
\hline Probit analysis & \\
\hline Instrumental variable. & \\
\hline
\end{tabular}

C)2018 PAPPIPTEK-LIPI All rights reserved

\section{INTRODUCTION}

Economic development in ASEAN economies has been successful and continuing. Most of the member countries become categorized as emerging or middle income countries.

\footnotetext{
* Corresponding Author.

E-mail: mtsuji@kobe-kiu.ac.jp
}

Meanwhile, further development requires transformation from a simple production based to a knowledge-based economy. This transformation can be accomplished by overcoming the middle income trap of the country. In order to achieve this, the further empowerment of regional firms to enhance innovation is required. This is a 
difficult and time-consuming task, since among Asian economies, only a few thus far had been upgraded to become OECD member countries, such as Japan and the Republic of Korea. There are many factors behind the promotion of innovation in an economy, as endogenous economic growth theory emphasizes, i.e. capital, labor and technology. In reality, it is difficult to improve the power of innovation within individual local small- and medium-sized enterprises (SMEs). This paper attempts to identify the factors behind innovation in firms from four ASEAN countries, namely Indonesia, the Philippines, Thailand, and Vietnam. In the analysis, Vietnam is divided by two regions, Hanoi and Ho Chi Minh, because their characteristics are quite different.

Since new information related to technology, know-how, management, consumer's needs, and so on, are necessary for innovation, and are mainly coming from MNCs, local SMEs need to firstly obtain such information and integrate it with firm's indigenous resources for successful innovation. The collaboration with entities outside the firm, such as transaction partners, universities, and local research institutions, come to be the center of research and should be analyzed in the framework of "open innovation" (Chesbrough, 2003, 2006a, 2006b). This paper terms these entities as external linkages. In developing countries, among external linkages, MNCs are of specific importance, since they have superiority in technology, know-how, and management, from which local firms have to absorb. Prior to absorbing new information, local firms have to not only initiate the connectivity to MNCs, through which local firms could obtain necessary information, but also enhance internal capability to obtain such information and to achieve innovation.

Innovation capacity is defined as the ability to continuously transform knowledge and ideas into new products, processes and systems for the benefit of the firm and its stakeholders (Lawson \& Samson, 2001). Cohen and Levinthal (1990) proposed capacity to absorb information outside the firm. Since then, various concepts were proposed. In reality, internal innovation capacity is tacit and contains various factors, including levels of technology; engineers' skills and ability; the ability of top management; R\&D units or section.
The contents of these concepts are overlapping with each other; accordingly, it is difficult to identify which factors really contribute to innovation. This is lessons-learned from previous literature. To avoid unnecessary complexity, to obtain clear results, this paper proposes an index which is a proxy for the internal innovation capacity of firms. In other words, this paper aims to construct an index from various factors related to creating innovation by using Analytical Hierarchical Process (AHP). The index was then employed to estimate how product innovation is related to internal capacity. This is an entirely new approach to research in this field.

Another problem which this study challenges is endogeneity associated to empirical estimation. Now, it is widely understood that simple Ordinary Least Squares (OLS) regression demonstrates only the correlation between dependent and independent variables, instead of causality. In this paper, the level of internal innovation capacity of firms is not exogenously given, but it is determined by firms. Firms wishing to obtain more profits should invest more in $R \& D$ or HRD, which could also enhance innovation. In this sense, investment to improve internal innovation capability is endogenously determined. Therefore, simple OLS may provide biased estimators, resulting in over-estimation. This paper aims to solve this problem by using the instrumental variable (IV) method.

Therefore, the research questions of this paper are summarized as follows.

RQ1: From which external linkages do SMEs obtain information associated to innovation?

RQ2: Does internal innovation capability determine the need to promote innovation?

The structure of the paper is as follows. Following an introduction, results of previous literature survey is presented. The contents of internal innovation capacity and the construction of an index are proposed in Section 3. Hypotheses and survey data are presented in Section 4. The estimation of method and its results are presented in Section 5. Discussions and conclusions are provided in the final section. 


\section{BACKGROUND LITERATURE}

\section{A. Innovation process}

This paper attempts to identify the factors behind innovation in individual firms. Since Cohen and Levinthal (1990) initiated the concept of absorptive capability, similar concepts were proposed (van den Bosch, Volderba, \& Boer, 1999; Stock, Greis, \& Fischer, 2001; Colin, 2006; Yang, Rui, \& Wang, 2006). Zahra and George (2002) reformulated the innovation process as a linear learning process consisting of four dimensions: acquisition, assimilation, transformation, and exploitation. Christensen and Kaufman (2009) defined absorptive capacity as a firm's ability to reorganize the value of new external knowledge and assimilate it to commercial ends. Therefore, absorptive capacity determines the competitive advantage of a firm (Barney, 1991). Nieto and Pilar (2005) categorized innovation capacity into groups such as 1) communication with the external environment; 2) level of know-how and experience within the organization; 3) diversity and overlaps in the knowledge structure; and 4) strategic positioning. Fosfuri and Tribo (2008) extended this process to a research model.

Since capability is not observable and knowledge or learning process is tacit and complex, various concepts, elements, and dimensions are required to take into consideration, it is difficult to discuss results of analyses in an unified way to develop theory. This paper, on the other hand, does not discuss fully semantic issues, but considers internal capacity which includes the technological level, such as the number of patents, production and $\mathrm{R} \& \mathrm{D}$ facilities, human resources such as the number of engineers with higher degrees or skills, the level of craftsmanship and work ethics, as well as organizational nature such as communication between workers and top management, speed of decision-making, and leadership of top management.

\section{B. Endogeneity of Variables and Instruments}

As already mentioned, economic variables used in empirical studies are more or less endogenous variables, whose values are determined inside the model. Without a proper estimation method, estimated coefficients tend to have biases. Therefore, it must be proven that the relationship between those variables is causation rather than simple correlation, namely the relationship is not "seemingly correlated". Coping with these theoretical problems, the treatment model and other methods are utilized. Studies by Kesidoua and Szirmai (2008) and Tsuji, Akematsu, Ueki, and Idota (2012) are examples of researches using IV regression models, or two-stage least square (2SLS) in this field. Lim, Stratopoulos, and Wirjanto (2011) used a more rigorous dynamic logit model.

Another standard methodology analyzing innovation process which has similar characteristics as that mentioned is Structural Equation Modeling (SEM), which has become popular these days. It can handle endogenous variables and clarify the causality among them by conducting regression as well as factor analysis. Liao, $\mathrm{Wu}, \mathrm{Hu}$, and Tsui (2010); Tsuji, Idota, Ueki, Shigeno, and Bunno (2016); and Tsuji, Minetaki, Akematsu, and Ueki (2011) are three examples.

Both approaches have their merits and shortcomings, and this paper follows the former, by looking through economic point of view.

\section{INTERNAL INNOVATION CAPACITY AND ANALYTIC HIERARCHY PROCESS (AHP)}

\section{A. Index of Internal Innovation Capacity}

In this study, the internal capacity of firms is constructed based on the questionnaire. The following three factors are postulated to consist of internal capacity: i) technology, ii) organizational learning, and iii) human resources. The technological factor is clearly the basis of innovation. These three factors constitute the "first layer" of internal capacity and are referred to as first layer factors. Moreover, each of these factors has its own detailed sub-factors, which form the "second layer" of internal capacity. These sub-factors are called second layer factors. Regarding the first layer of i) technology, it consists of the following two second layer factors:

a. "Ratio of $R \& D$ expenditure to sales at present", asked as Q19.1 
b. "Established Original Equipment Manufacturer (OEM) (Q8)", asked about high technical ability.

The first layer of ii) organizational learning indicates whether the managerial organization is designed and functioning to encourage exchange and a sharing of information among employees. This first layer factor consists of the following three second layer factors:

c. "Adopted ISO9000/14000 (Q17.1-2)"

d. "Cross-functional team (Q21)"

e. "Practicing QC (quality control) circle (Q22.1)"

Finally, the first layer factor of iii) human resources is an important factor for engaging in innovation activities as well as for designing and managing $\mathrm{R} \& \mathrm{D}$. This consists of the following three second layer factors:

f. "Career of top management (Q35.3-4, 8)"

g. "Career of factory manager $(\mathrm{Q} 36,39)$ "

h. "Training/HRD program $(\mathrm{Q} 41,42) . "$

Figure 1 and Table 1 show the tree structure of the index and associated questions in the questionnaire.

\section{B. Analytic Hierarchy Process (AHP) Approach}

As for the construction of an internal innovation capacity index, there are several analytical methods to construct such indices, namely factor analysis, principle component analysis, and AHP. After carefully constructing and examining indices based on these methods, AHP is finally selected as the theory to create an index, since factor analysis and principle component seem not to select only suitable variables for an index or categories, that is, they contain some irrelevant variables (Ogawa, Idota, Bunno, \& Tsuji, 2009; Idota, Ogawa, Bunno, \& Tsuji, 2012).

AHP attempts to give people's decisionmaking a numerical value (Saaty, 1986a; 1986b). For example, when making a purchase, on what basis does a consumer decide? AHP formulates the mechanism of such decision-making. It allows us to give a numerical value to vague parts in people's decision-making, with a possible application to a wide array of fields. An individual makes a decision based on his/her own criteria. Normally, several evaluation criteria exist which tend to conflict with each other. In a consumer's decision-making process, the "problem" of

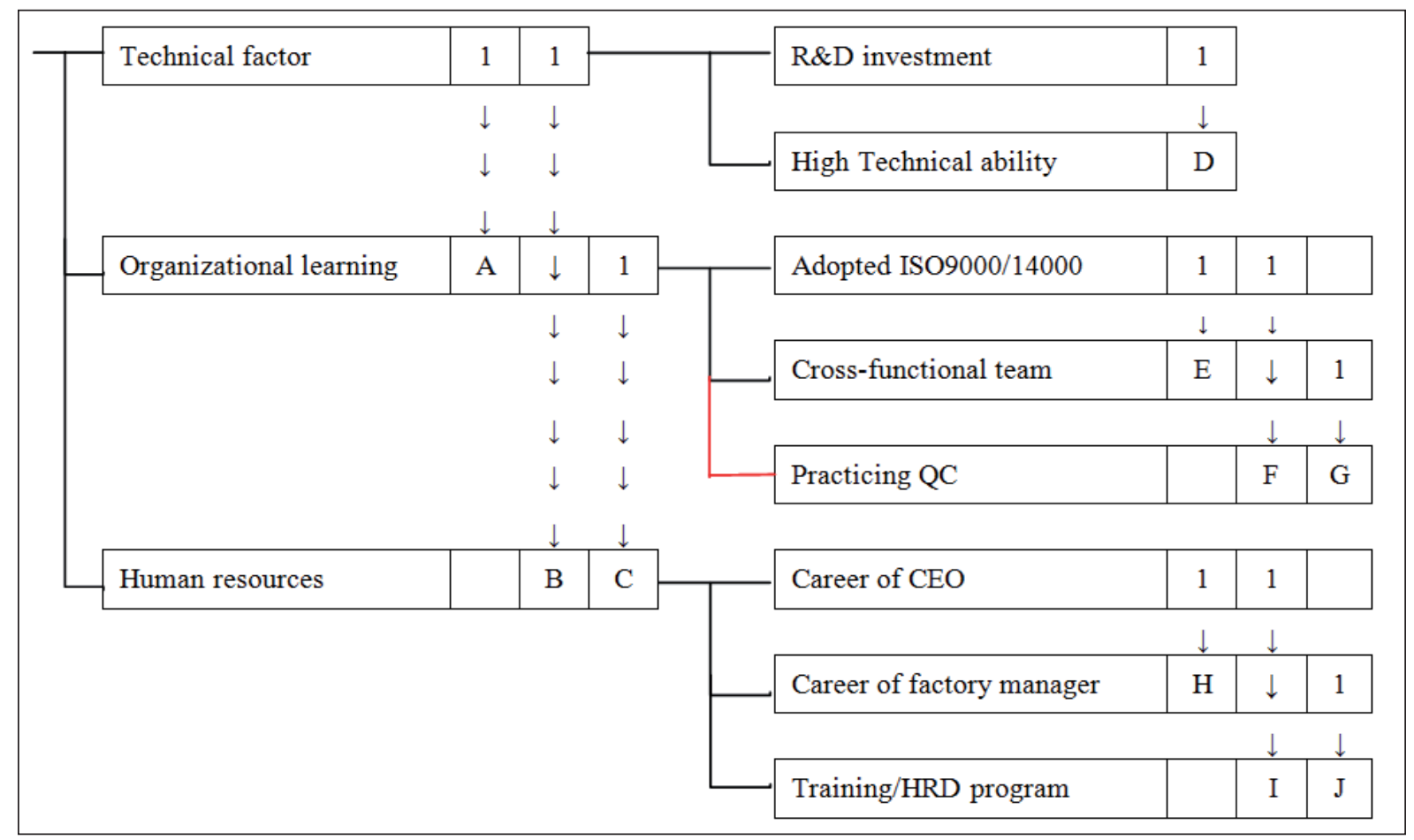

Figure 1. Internal Innovation Capacity: AHP Hierarchy Diagram 
Table 1.

Variables and Questions Consisting of Internal Innovation Capacity

\begin{tabular}{|c|c|}
\hline \multicolumn{2}{|c|}{ Second Layer of Technological Factor } \\
\hline R\&D investment & Q19.1. Ratio between R\&D expenditure and sales \\
\hline High Technical ability & Q8 Established Original Equipment Manufacturer (OEM) \\
\hline \multicolumn{2}{|c|}{ Second Layer of Organizational Learning Factor } \\
\hline Adopted ISO9000/14000 & $\begin{array}{l}\text { Q17.1. Adopted ISO } 9000 \text { series (ISO 9000/9001) } \\
\text { Q17.2. Adopted ISO } 14000 \text { series (ISO 14000/14001) }\end{array}$ \\
\hline Cross-functional team & $\begin{array}{l}\text { Q21. Cross-functional team: Market research } \\
\text { Cross-functional team: Research } \\
\text { Cross-functional team: Development } \\
\text { Cross-functional team: Production engineering } \\
\text { Cross-functional team: Sales \& marketing }\end{array}$ \\
\hline Practicing QC & $\begin{array}{l}\text { Q22.1. Operate a QC circle } \\
\text { Have a system/practice to disseminate successful experiences of a QC circle } \\
\text { Have a system/practice to learn from successful experiences of a QC circle } \\
\text { Have a system/practice to share successful experiences of a QC circle }\end{array}$ \\
\hline \multicolumn{2}{|c|}{ Second Layer of Human Resources } \\
\hline Career of CEO & $\begin{array}{l}\text { Q35.3. Educational background of top management } \\
\text { Q35.4. Top management study outside country } \\
\text { Q35.8. Top management has experiences working for MNCs/JVs }\end{array}$ \\
\hline Career of factory manager & $\begin{array}{l}\text { Q36. Have a factory manager } \\
\text { Q39. Factory manager has experiences working for } \mathrm{MNC} / \mathrm{JVs}\end{array}$ \\
\hline Training/HRD program & $\begin{array}{l}\text { Q41. Have training program for blue-collar workers to upgrade specialized skills } \\
\text { Q42. Have HRD program for blue-collar workers to provide cross-training } \\
\text { /job rotation }\end{array}$ \\
\hline
\end{tabular}

what to choose comes first, followed by several "alternatives." AHP attempts to comprehend the process of decision-making, assuming that there are some criteria relating to the specific problem and some alternatives. Therefore, AHP's approach is to construct an individual's decision-making according to a hierarchic structure.

In order to apply AHP analysis, all factors in each layer demand pair-wise comparisons. Pair-wise comparisons take the value of one factor as one, while the value of another factor is measured. To be concrete, scholars or specialists in this field, including three economics professors, three business management professors, two business consultants and three presidents of companies, were asked to choose a number from $1 / 9,2 / 9 \ldots, 8 / 9,1,2,3 \ldots, 9$. If they choose 1 , equal importance is placed on two factors. 1/9 (9) implies that its factor is the least (most) important compared to another. Each answer of the pairwise comparison is termed a "score," which is the basis of weights of factors. The obtained weights of factors of the first and second layers are shown in Table 2.

Table 2.

Weights of Factors by AHP

\begin{tabular}{llll}
\hline \multirow{2}{*}{ Technological Factor } & \multirow{2}{*}{0.490} & R\&D investment & 0.240 \\
\cline { 3 - 4 } & & High technical ability & 0.760 \\
\hline \multirow{2}{*}{$\begin{array}{l}\text { Organizational Learning } \\
\text { Factor }\end{array}$} & \multirow{2}{*}{0.164} & Adopted ISO9000/14000 & 0.104 \\
\cline { 3 - 4 } \cline { 3 - 3 } & & Cross-function team & 0.623 \\
\cline { 3 - 4 } Human Resources & \multirow{2}{*}{0.346} & Practicing QC & 0.273 \\
\cline { 3 - 4 } & & Career of CEO & 0.675 \\
\cline { 3 - 4 } & & Training/HRD program & 0.153 \\
\hline
\end{tabular}




\section{Distribution of the Capacity Index}

Based on the weights of factors by AHP, the distribution of the internal innovation capacity index of the five regions (Indonesia, Thailand, the Philippines, the Ho Chi Minh City area, and the Hanoi area) is shown in Figure 2. The average value of the index of the five areas is 0.388 and the averages of Indonesia, Thailand, the Philippines, the Ho Chi Minh City area, and the Hanoi area are $0.398,0.400,0.338,0.441$, and 0.382 , respectively (see Table 3 ). As for the average value of each, the Ho Chi Minh City area has the largest value, while that of the Philippines is lower than the average. Figure 2 shows that the shapes of distribution of the five areas are also different from the five areas' average. Ho Chi Minh City and Hanoi are polarized around their averages. Indonesia and the Philippines have concentrate below their averages, while Thailand has concentrate above their averages. Factors underlying the differences in these five areas will be examined.

\section{HYPOTHESIS AND SUMMARY OF DATA}

\section{A. Hypothesis}

Based on authors' previous studies including Tsuji et al. (2011, 2012, 2016, 2017), and Idota et al. (2012), the relationship between innovation, internal innovation capacity and external linkages was examined. This paper attempts to examine these relationships among the factors of innovation, using econometric analysis. The hypotheses can be summarized as follows.

Hypothesis I: Internal innovation capacity affects product innovation.

Hypothesis II: External linkages have no direct effect on product innovation.

Hypothesis III: External linkages enhance internal innovation capacity.

\section{B. Surveys Conducted}

To examine the above hypotheses, we developed questionnaire survey projects in four countries

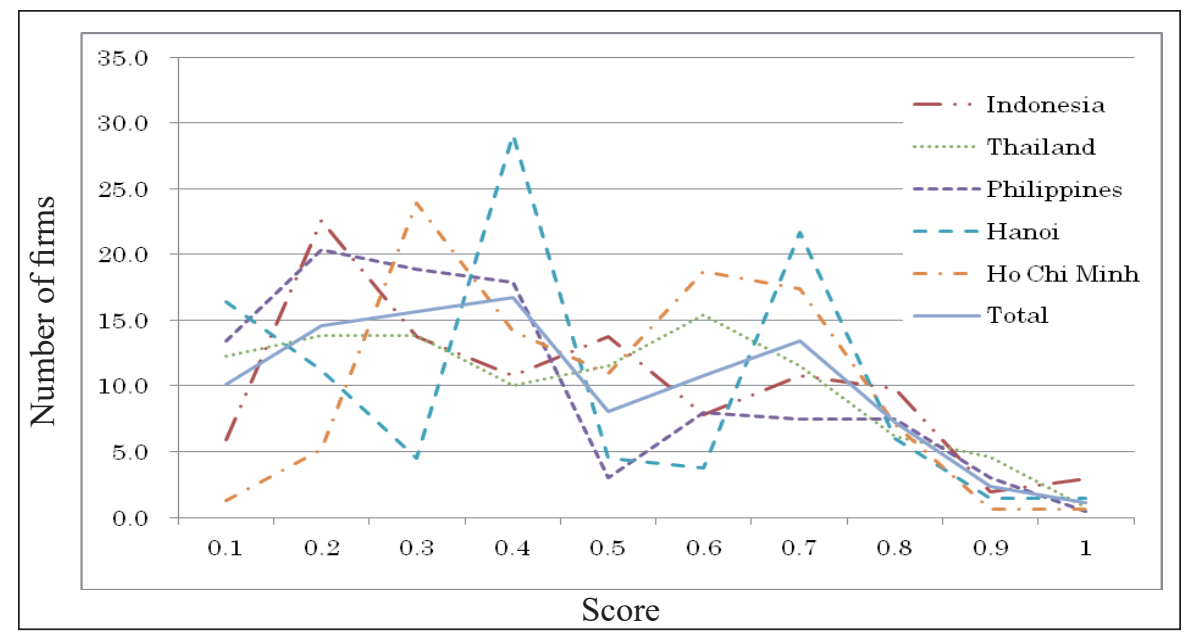

Figure 2. Distribution of Innovation Capacity Index by Area

Table 3.

Basic Statistics of Innovation Capacity Index by Area

\begin{tabular}{lrrrrrrr}
\hline & Indonesia & \multicolumn{1}{c}{ Thailand } & Philippines & Ho Chi Minh & Hanoi & Vietnam & Average \\
\hline \hline Average & 0.398 & 0.400 & 0.338 & 0.441 & 0.382 & 0.413 & 0.388 \\
Median & 0.356 & 0.412 & 0.288 & 0.457 & 0.321 & 0.342 & 0.332 \\
Maximum & 0.957 & 0.954 & 0.919 & 0.933 & 0.927 & 0.933 & 0.957 \\
Minimum & 0.017 & 0.000 & 0.000 & 0.065 & 0.056 & 0.056 & 0.000 \\
\hline
\end{tabular}

Source: calculated by the Authors 
including Indonesia, the Philippines, Thailand and Vietnam. Regarding Vietnam, two regions were selected for research, Ha Noi and Ho Chi Minh. There were two reasons: i) our previous papers discussed not regions but Vietnam as a one economy (Tsuji, Miyahara, and Ueki, 2008; Tsuji et al., 2012). This paper was aimed to separate the two regions, since there are major industrial districts in Southeast Asia with different characteristics and local business ties; and ii) to balance the sample size because Vietnam has the largest number of responses which need to be divided into two regions.

The survey in each country was conducted by local university or public research institute. The authors developed questionnaire in English. Each country team translated their questionnaire into local language to collect more responses from local firms. The questionnaire was sent and collected by postal mail and/or e-mail by the national teams during the period between November 2011 and January 2012. Each country team took appropriate follow-up methods, such as phone calls and firm visits, to encourage firms to participate in the survey and obtain valid responses as many as possible. Each country reported the valid responses as follows: Ha Noi (134) and Ho Chi Minh (155), thus making Vietnam (289); the Philippines (201); Indonesia (102); and Thailand (130). Therefore, 722 valid responses were reported.

\section{Profile of Firms}

In this section, the descriptive analysis of the characteristics of sample firms is presented. The following four variables are controlled in estimations.

\section{Years of Establishment}

Table 4 indicates that $55.7 \%$ of Vietnamese, $34.3 \%$ of Indonesian and $28.9 \%$ of Filipino firms started operation between 2001 and 2010. Another $46.3 \%$ of Filipino, $36.1 \%$ of Thai, $31.8 \%$ of Vietnamese and $27.5 \%$ of Indonesian firms replied that they had started between 1991 and 2000. $36.1 \%$ of Thai firms replied that their establishment dated from between 1981 and 1990, and they had longer operation years compared to firms in other countries that were established less than 20 years ago.

\section{Capital Structure}

According to Table 5, most firms are 100\% locally owned in all countries: Vietnam (60.2\%), Indonesia (71.6\%), the Philippines (49.3\%), and Thailand $(62.4 \%)$, as shown in Table 2. The second biggest category is $100 \%$ foreignowned (MNC), with Vietnam (31.5\%), Indonesia $(17.6 \%)$, and the Philippines (32.8\%). On the other hand, in Thailand, joint ventures (JV, locally and foreign-owned) account for $21.6 \%$, as the second largest type.

Table 4.

Year of Establishment

\begin{tabular}{|c|c|c|c|c|c|c|c|c|c|c|c|c|c|c|}
\hline & \multicolumn{2}{|c|}{ Ho Chi Minh } & \multicolumn{2}{|c|}{ Hanoi } & \multicolumn{2}{|c|}{ Vietnam } & \multicolumn{2}{|c|}{ Indonesia } & \multicolumn{2}{|c|}{ Philippines } & \multicolumn{2}{|c|}{ Thailand } & \multicolumn{2}{|c|}{ Total } \\
\hline & Freq. & $\%$ & Freq. & $\%$ & Freq. & $\%$ & Freq. & $\%$ & Freq. & $\%$ & Freq. & $\%$ & Freq. & $\%$ \\
\hline . - 1970 & 2 & 1.3 & 7 & 5.2 & 9 & 3.1 & 7 & 6.9 & 5 & 2.5 & 11 & 10.2 & 32 & 4.6 \\
\hline 1971 - 1980 & 13 & 8.4 & 3 & 2.2 & 16 & 5.5 & 16 & 15.7 & 11 & 5.5 & 3 & 2.8 & 46 & 6.6 \\
\hline 1981 - 1990 & 8 & 5.2 & 2 & 1.5 & 10 & 3.5 & 16 & 15.7 & 33 & 16.4 & 30 & 27.8 & 89 & 12.7 \\
\hline $1991-2000$ & 53 & 34.2 & 39 & 29.1 & 92 & 31.8 & 28 & 27.5 & 93 & 46.3 & 39 & 36.1 & 252 & 36.0 \\
\hline $2001-2010$ & 79 & 51.0 & 82 & 61.2 & 161 & 55.7 & 35 & 34.3 & 58 & 28.9 & 23 & 21.3 & 277 & 39.6 \\
\hline $2011-$ & 0 & 0.0 & 1 & 0.7 & 1 & 0.3 & 0 & 0.0 & 1 & 0.5 & 2 & 1.9 & 4 & 0.6 \\
\hline Total & 155 & 100 & 134 & 100 & 289 & 100 & 102 & 100 & 201 & 100 & 108 & 100 & 700 & 100 \\
\hline
\end{tabular}

Table 5.

Capital Structure of Firms

\begin{tabular}{|l|r|r|r|r|r|r|r|r|r|r|r|r|r|r|r|r|r|}
\hline & \multicolumn{2}{|c|}{ Ho Chi Minh } & \multicolumn{2}{|c|}{ Hanoi } & \multicolumn{2}{c|}{ Vietnam } & \multicolumn{2}{c|}{ Indonesia } & \multicolumn{2}{c|}{ Philippines } & \multicolumn{3}{c|}{ Thailand } & \multicolumn{2}{c|}{ Total } \\
& Freq. & \multicolumn{1}{c|}{$\%$} & Freq. & $\%$ & Freq. & $\%$ & Freq. & $\%$ & Freq. & $\%$ & Freq. & $\%$ & Freq. & $\%$ \\
\hline \hline $100 \%$ Locally-owned & 79 & 51 & 95 & 71 & 174 & 60.2 & 73 & 71.6 & 99 & 49.3 & 78 & 62.4 & 424 & 59.1 \\
\hline $100 \%$ Foreign-owned (MNC) & 58 & 37.4 & 33 & 24.6 & 91 & 31.5 & 18 & 17.6 & 66 & 32.8 & 20 & 16 & 195 & 27.2 \\
\hline Joint Venture & 18 & 11.6 & 6 & 4.8 & 24 & 8.3 & 11 & 10.8 & 36 & 17.9 & 27 & 21.6 & 98 & 13.7 \\
\hline \multicolumn{1}{|c|}{ Total } & 155 & 100 & 134 & 100 & 289 & 100 & 102 & 100 & 201 & 100 & 125 & 100 & 717 & 100 \\
\hline
\end{tabular}




\section{Number of Full-Time Employees}

Almost half of the firms have 20 to 199 employees (Table 6). The second highest category is that the larger firms in Vietnam replied to governing 200 to 299 employees (13.1\%). Meanwhile, about $60 \%$ and $50 \%$ firms in Vietnam and Thailand respectively have less than 100 employees.

\section{Total Assets}

Table 7 shows that $27.4 \%$ of responding firms have assets ranging from US\$ 1 million to 4.9 million. However, the largest category in the Philippines is from US $\$ 100,000$ to 499,000 $(30.3 \%)$ and for Thailand, it is both from US\$ 1 million to 4.9 million (31.6\%) and from US\$ 10 million and above (31.6\%).

\section{Main Business Activity}

Table 8 indicates the main business activity. For Vietnam, the business activity mainly covers metal products $(22.1 \%)$, plastic and rubber products $(16.3 \%)$, and machinery, equipment and tools (12.8\%), while in Indonesia, food, beverages and tobacco (26.3\%) are among the largest. The Philippines has metal products (12.9\%), food, beverages and tobacco (11.9\%), apparel and leather (11.9\%), and other electronics \& components $(10.9 \%)$, while Thailand has other business activities (25.0\%), automobiles and auto parts $(18.0 \%)$, and other electronics \& components $(11.7 \%)$.

Table 6.

Number of Full-time Employees

\begin{tabular}{|c|c|c|c|c|c|c|c|c|c|c|c|c|c|c|}
\hline & \multicolumn{2}{|c|}{ Ho Chi Minh } & \multicolumn{2}{|c|}{ Hanoi } & \multicolumn{2}{|c|}{ Vietnam } & \multicolumn{2}{|c|}{ Indonesia } & \multicolumn{2}{|c|}{ Philippines } & \multicolumn{2}{|c|}{ Thailand } & \multicolumn{2}{|c|}{ Total } \\
\hline & Freq. & $\%$ & Freq. & $\%$ & Freq. & $\%$ & Freq. & $\%$ & Freq. & $\%$ & Freq. & $\%$ & Freq. & $\%$ \\
\hline $1-19$ persons & 2 & 1.3 & 9 & 6.7 & 11 & 3.8 & 5 & 4.9 & 17 & 8.5 & 19 & 15.3 & 52 & 7.3 \\
\hline $20-49$ & 11 & 7.1 & 27 & 20.1 & 38 & 13.1 & 14 & 13.7 & 48 & 23.9 & 25 & 20.2 & 125 & 17.5 \\
\hline $50-99$ & 28 & 18.1 & 30 & 22.4 & 58 & 20.1 & 24 & 23.5 & 53 & 26.4 & 16 & 12.9 & 151 & 21.1 \\
\hline $100-199$ & 44 & 28.4 & 10 & 7.5 & 54 & 18.7 & 14 & 13.7 & 40 & 19.9 & 18 & 14.5 & 126 & 17.6 \\
\hline $200-299$ & 24 & 15.5 & 14 & 10.4 & 38 & 13.1 & 9 & 8.8 & 15 & 7.5 & 12 & 9.7 & 74 & 10.3 \\
\hline $300-399$ & 12 & 7.7 & 5 & 3.7 & 17 & 5.9 & 6 & 5.9 & 5 & 2.5 & 9 & 7.3 & 37 & 5.2 \\
\hline $400-499$ & 10 & 6.5 & 5 & 3.7 & 15 & 5.2 & 4 & 3.9 & 5 & 2.5 & 2 & 1.6 & 26 & 3.6 \\
\hline $500-999$ & 18 & 11.6 & 10 & 7.5 & 28 & 9.7 & 9 & 8.8 & 14 & 7 & 10 & 8.1 & 61 & 8.5 \\
\hline $1,000-1,499$ & 1 & 0.6 & 14 & 10.4 & 15 & 5.2 & 5 & 4.9 & 1 & 0.5 & 2 & 1.6 & 23 & 3.2 \\
\hline $1,500-1,999$ & 2 & 1.3 & 2 & 1.5 & 4 & 1.4 & 2 & 2 & 2 & 1 & 1 & 0.8 & 9 & 1.3 \\
\hline 2,000 and above & 3 & 1.9 & 8 & 6 & 11 & 3.8 & 10 & 9.8 & 1 & 0.5 & 10 & 8.1 & 32 & 4.5 \\
\hline Total & 155 & 100 & 134 & 100 & 289 & 100 & 102 & 100 & 201 & 100 & 124 & 100 & 716 & 100 \\
\hline
\end{tabular}

Table 7.

Total Assets

\begin{tabular}{|c|c|c|c|c|c|c|c|c|c|c|c|c|c|c|}
\hline & \multicolumn{2}{|c|}{ Ho Chi Minh } & \multicolumn{2}{|c|}{ Hanoi } & \multicolumn{2}{|c|}{ Vietnam } & \multicolumn{2}{|c|}{ Indonesia } & \multicolumn{2}{|c|}{ Philippines } & \multicolumn{2}{|c|}{ Thailand } & \multicolumn{2}{|c|}{ Total } \\
\hline & Freq. & $\%$ & Freq. & $\%$ & Freq. & $\%$ & Freq. & $\%$ & Freq. & $\%$ & Freq. & $\%$ & Freq. & $\%$ \\
\hline Less than 10,000 & 1 & 0.6 & 6 & 4.5 & 7 & 2.4 & 14 & 13.7 & 8 & 4 & 3 & 3.8 & 32 & 4.8 \\
\hline $10,000-24,999$ & 0 & 0 & 12 & 9 & 12 & 4.2 & 4 & 3.9 & 5 & 2.5 & 1 & 1.3 & 22 & 3.3 \\
\hline $25,000-49,999$ & 2 & 1.3 & 9 & 6.7 & 11 & 3.8 & 3 & 2.9 & 10 & 5 & 1 & 1.3 & 25 & 3.7 \\
\hline $50,000-74,999$ & 6 & 3.8 & 4 & 3 & 10 & 3.5 & 3 & 2.9 & 9 & 4.5 & 0 & 0 & 22 & 3.3 \\
\hline 75,000 - 99,999 & 10 & 6.5 & 4 & 3 & 14 & 4.8 & 5 & 4.9 & 9 & 4.5 & 0 & 0 & 28 & 4.2 \\
\hline $100,000-499,000$ & 23 & 14.8 & 10 & 7.5 & 33 & 11.4 & 20 & 19.6 & 61 & 30.3 & 10 & 12.7 & 124 & 18.5 \\
\hline $500,000-999,999$ & 33 & 21.3 & 10 & 7.5 & 43 & 14.9 & 6 & 5.9 & 17 & 8.5 & 5 & 6.3 & 71 & 10.6 \\
\hline 1 million - 4.9 mil. & 47 & 30.3 & 40 & 3 & 87 & 30.1 & 22 & 21.6 & 50 & 24.9 & 25 & 31.6 & 184 & 27.4 \\
\hline 5 mil. - 9.9 mil. & 25 & 16.1 & 20 & 14.9 & 45 & 15.6 & 5 & 4.9 & 17 & 8.5 & 9 & 11.4 & 76 & 11.3 \\
\hline 10 million and above & 8 & 5.2 & 19 & 14.2 & 27 & 9.3 & 20 & 19.6 & 15 & 7.5 & 25 & 31.6 & 87 & 13 \\
\hline Total & 155 & 100 & 134 & 100 & 289 & 100 & 102 & 100 & 201 & 100 & 79 & 100 & 671 & 100 \\
\hline
\end{tabular}


Table 8.

Main Business Activity of Firms

\begin{tabular}{|c|c|c|c|c|c|c|c|c|c|c|c|c|c|c|}
\hline & \multicolumn{2}{|c|}{ Ho Chi Minh } & \multicolumn{2}{|c|}{ Hanoi } & \multicolumn{2}{|c|}{ Vietnam } & \multicolumn{2}{|c|}{ Indonesia } & \multicolumn{2}{|c|}{ Philippines } & \multicolumn{2}{|c|}{ Thailand } & \multicolumn{2}{|c|}{ Total } \\
\hline & Freq. & $\%$ & Freq. & $\%$ & Freq. & $\%$ & Freq. & $\%$ & Freq. & $\% \mathrm{I}$ & Freq. & $\%$ & Freq. & $\%$ \\
\hline Food, beverages, tobacco & 1 & 0.6 & 0 & 0 & 1 & 0.3 & 20 & 26.3 & 24 & 11.9 & 12 & 9.4 & 57 & 8.2 \\
\hline Textiles & 17 & 11 & 4 & 3 & 21 & 7.3 & 2 & 2.6 & 7 & 3.5 & 2 & 1.6 & 32 & 4.6 \\
\hline Apparel, leather & 1 & 0.6 & 3 & 2.2 & 4 & 1.4 & 6 & 7.9 & 24 & 11.9 & 7 & 5.5 & 41 & 5.9 \\
\hline Wood, wood products & 2 & 13 & 1 & 0.7 & 3 & 1 & 4 & 5.3 & 6 & 3 & 1 & 0.8 & 14 & 2 \\
\hline Paper, paper products, printing & 3 & 1.9 & 3 & 2.2 & 6 & 2.1 & 7 & 9.2 & 5 & 2.5 & 1 & 0.8 & 19 & 2.7 \\
\hline Coal, petroleum products & 1 & 0.6 & 1 & 0.7 & 2 & 0.7 & 1 & 1.3 & 0 & 0 & 0 & 0 & 3 & 0.4 \\
\hline Chemicals, chemical products & 5 & 3.2 & 3 & 2.2 & 8 & 2.8 & 2 & 2.6 & 4 & 2 & 0 & 0 & 14 & 2 \\
\hline Plastic, rubber products & 30 & 19.4 & 17 & 12.7 & 47 & 16.3 & 6 & 7.9 & 19 & 9.5 & 6 & 4.7 & 78 & 11.2 \\
\hline Other non-metallic mineral products & 2 & 1.3 & 1 & 0.7 & 3 & 1 & 0 & 0 & 11 & 5.5 & 1 & 0.8 & 15 & 2.2 \\
\hline Iron, steel & 8 & 5.2 & 1 & 0.7 & 9 & 3.1 & 6 & 7.9 & 6 & 3 & 7 & 5.5 & 28 & 4 \\
\hline Non-ferrous metals & 3 & 1.9 & 0 & 0 & 3 & 1 & 0 & 0 & 0 & 0 & 2 & 1.6 & 5 & 0.7 \\
\hline Metal products & 18 & 11.6 & 46 & 34.3 & 64 & 22.1 & 6 & 7.9 & 26 & 12.9 & 7 & 5.5 & 103 & 14.8 \\
\hline Machinery, equipment, tools & 26 & 16.8 & 11 & 8.2 & 37 & 12.8 & 3 & 3.9 & 10 & 5 & 9 & 7 & 59 & 8.5 \\
\hline Computers \& computer parts & 3 & 1.9 & 1 & 0.7 & 4 & 1.4 & 0 & 0 & 0 & 0 & 3 & 2.3 & 7 & 1 \\
\hline Other electronics \& components & 9 & 5.8 & 19 & 14.2 & 28 & 9.7 & 6 & 7.9 & 22 & 10.9 & 15 & 11.7 & 71 & 10.2 \\
\hline Precision instruments & 7 & 4.5 & 0 & 0 & 7 & 2.4 & 1 & 1.3 & 2 & 1 & 0 & 0 & 10 & 1.4 \\
\hline Automobile, auto parts & 11 & 7.1 & 12 & 9 & 23 & 8 & 4 & 5.3 & 16 & 8 & 23 & 18 & 66 & 9.5 \\
\hline Other transportation equipments and parts & 0 & 0 & 11 & 8.2 & 11 & 3.8 & 2 & 2.6 & 4 & 2 & 0 & 0 & 17 & 2.4 \\
\hline Other business activity & 8 & 5.2 & 0 & 0 & 8 & 2.8 & 0 & 0 & 15 & 7.5 & 32 & 25 & 55 & 7.9 \\
\hline Total & 155 & 100 & 134 & 100 & 289 & 100 & 76 & 100 & 201 & 100 & 128 & 100 & 694 & 100 \\
\hline
\end{tabular}

\section{Dependent variable: Achievements of innovation}

The construction of variables related to product innovation is based on the following four categories of innovation:

1) Innovation type I: introduction of a new product, redesigning packaging or significantly changing the appearance design.

2) Innovation type II: introduction of a new product, significantly improving existing products with respect to their capabilities, user friendliness, components, subsystems, etc.

3) Innovation type III: development of a totally new product based on the "existing" technologies.

4) Innovation type IV: development of a totally new product based on "new" technologies.
For each category, the respondents were asked whether they had achieved, attempted, or not attempted innovation. The value of dependent variable Innovation depends on the question regarding whether the firm achieved product innovation or not. It takes zero if respondent replied "not attempted" or "attempted," while it takes one if it said "achieved". The innovation situation in each individual country is summarized in Figure 3, which shows that the quality of innovation increases from Type I to Type IV, and the distribution of Vietnamese respondents are typical. However, in the case of Indonesia and the Philippines, a peak is observed at Type II, and in the case of Thailand, a peak is located at Type III. The average of the four countries is indicated by "Total." 


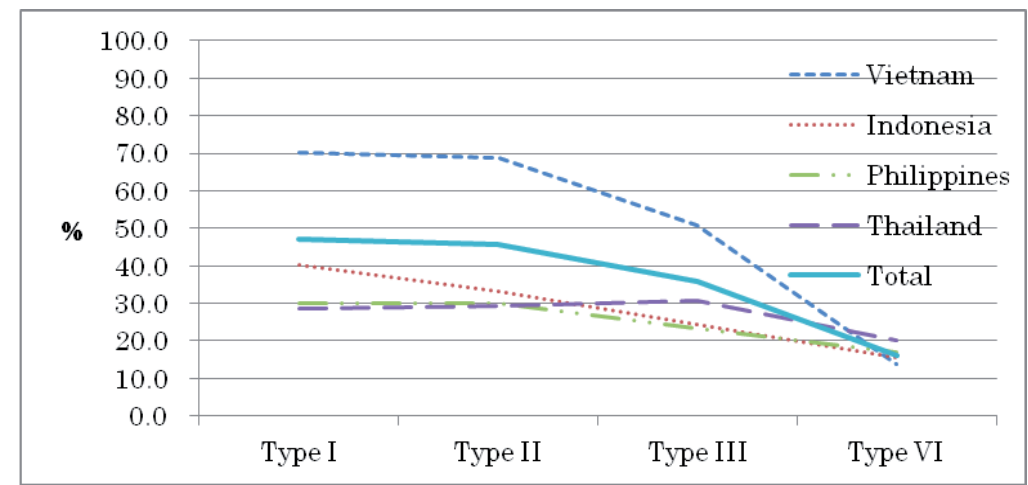

Type I Redesigning packaging or significantly changing appearance design

Type II Significantly improving existing products

Type III New product based on the existing technologies

Type IV New product based on new technologies

Note: Frequency indicates the percentage of firms which replied to have achieved the relevant innovation type.

Figure 3. Product Innovation by Country

\section{E. Independent Variables}

\section{External Linkages}

This study asked resonances whether they obtain information associated to innovation from the following 13 external linkages:

1) Final consumer

2) Competitor

3) Trading company

4) Consultant

5) Local customer (100\% local capital)

6) Local supplier (100\% local capital)

7) $\mathrm{MNC} / \mathrm{JV}$ customer located in country

8) $\mathrm{MNC} / \mathrm{JV}$ supplier located in country

9) $\mathrm{MNC} / \mathrm{JV}$ customer located in a foreign country

10) $\mathrm{MNC} / \mathrm{JV}$ supplier located in a foreign country

11) Public organization

12) Local business organization

13) University or public research institute

\section{Index of Internal Innovation Capacity}

This variable was already explained in the previous section. The index of each respondent firm calculated by AHP is taken as an independent variable.

\section{Other Controlled Variables}

Other independent variables are as follows: i) firm's characteristics, including year of establishment; ii) number of full-time employees (categorical data); iii) main business activities (dummy); and country dummy. Finally, summary statistics of main variables are summarized in Table 9.

\section{ESTIMATION MODEL}

\section{A. Model}

The main purpose of this empirical study is to verify the sources of product innovation. Since there are two major sources of innovation, namely internal capacity and external linkages which are taken as independent variables, this section examines whether internal capacity and/ or external linkages promote product innovation in the framework of two categories of sources included in one estimation model.

The procedure of estimation is as follows. i) Since external linkages are exogenous, first step is to estimate the expected value of internal capacity with both external linkages and instruments being independent variables; ii) Then this expected value is used for estimating product innovation. This paper has four categories of product innovation. We estimate equations 1 ) and 2) for each innovation separately, and the former 
Table 9.

Summary Statistics

\begin{tabular}{|c|c|c|c|c|c|c|}
\hline & Variables & $\mathrm{N}$ & Mean & S.D. & Min & Max \\
\hline \multicolumn{7}{|c|}{ Dependent variables } \\
\hline \multirow[t]{4}{*}{ Innovation } & e I: Redesigning packaging or changing appearance design & 722 & 0.47 & 0.50 & 0 & 1 \\
\hline & e II: Significantly improving existing products & 722 & 0.46 & 0.50 & 0 & 1 \\
\hline & e III: New product based on the existing technologies & 722 & 0.36 & 0.48 & 0 & 1 \\
\hline & Je IV: New product based on new technologies & 722 & 0.16 & 0.37 & 0 & 1 \\
\hline \multicolumn{2}{|l|}{ Capacity index } & 722 & 0.39 & 0.23 & 0 & 0.96 \\
\hline \multicolumn{7}{|c|}{ Independent variables } \\
\hline \multicolumn{2}{|c|}{ Year of establishment } & 700 & 1995.3 & 12.3 & 1894 & 2011 \\
\hline \multicolumn{2}{|c|}{ No. of full-time employees (category) } & 716 & 4.43 & 2.61 & 1 & 11 \\
\hline \multirow[t]{12}{*}{ External linkage } & Competitor & 722 & 0.93 & 0.26 & 0 & 1 \\
\hline & Buyer or trading company & 722 & 0.91 & 0.28 & 0 & 1 \\
\hline & Consultant & 722 & 0.89 & 0.32 & 0 & 1 \\
\hline & Local customer (100\% local capital) & 722 & 0.92 & 0.27 & 0 & 1 \\
\hline & Local supplier (100\% local capital) & 722 & 0.92 & 0.27 & 0 & 1 \\
\hline & MNC/JV customer located in country & 722 & 0.83 & 0.38 & 0 & 1 \\
\hline & MNC/JV supplier located in country & 722 & 0.83 & 0.38 & 0 & 1 \\
\hline & MNC/JV customer located in a foreign country & 722 & 0.77 & 0.42 & 0 & 1 \\
\hline & MNC/JV supplier located in a foreign country & 722 & 0.80 & 0.40 & 0 & 1 \\
\hline & Public organization & 722 & 0.83 & 0.38 & 0 & 1 \\
\hline & Local business organization & 722 & 0.86 & 0.35 & 0 & 1 \\
\hline & University or public research institute & 722 & 0.78 & 0.41 & 0 & 1 \\
\hline \multicolumn{2}{|l|}{ Hanoi (dummy) } & 722 & 0.19 & 0.39 & 0 & 1 \\
\hline \multicolumn{2}{|c|}{ Ho Chi Minh (dummy) } & 722 & 0.21 & 0.41 & 0 & 1 \\
\hline \multicolumn{2}{|c|}{ Indonesia (dummy) } & 722 & 0.14 & 0.35 & 0 & 1 \\
\hline \multicolumn{2}{|c|}{ Thailand (dummy) } & 722 & 0.18 & 0.38 & 0 & 1 \\
\hline \multicolumn{2}{|c|}{ The Philippines(dummy) } & 722 & 0.28 & 0.32 & 0 & 1 \\
\hline \multicolumn{7}{|c|}{ Instrumental variables } \\
\hline \multicolumn{2}{|c|}{$100 \%$ foreign-owned (MNC) } & 717 & 0.27 & 0.45 & 0 & 1 \\
\hline \multicolumn{2}{|c|}{ ASEAN-Japan FTA in export } & 722 & 0.09 & 0.29 & 0 & 1 \\
\hline \multicolumn{2}{|c|}{ Manufacturer of main production machineries provide training to machine operator } & 719 & 0.70 & 0.46 & 0 & 1 \\
\hline \multicolumn{2}{|c|}{ Have affiliates in Japan } & 722 & 0.16 & 0.37 & 0 & 1 \\
\hline \multicolumn{2}{|c|}{ Co-development of new capital goods with capital goods producers } & 715 & 0.37 & 0.48 & 0 & 1 \\
\hline \multicolumn{2}{|c|}{ Increased degree of automation of production process } & 717 & 0.58 & 0.49 & 0 & 1 \\
\hline \multicolumn{2}{|c|}{ Investment project has been granted government's preferential treatment } & 718 & 0.21 & 0.41 & 0 & 1 \\
\hline \multicolumn{2}{|c|}{ IT system for information sharing connected to development } & 722 & 0.16 & 0.37 & 0 & 1 \\
\hline \multicolumn{2}{|c|}{ Installed productive machines made in Japan } & 722 & 0.20 & 0.40 & 0 & 1 \\
\hline
\end{tabular}

uses a Probit model, whereas the latter uses a Tobit model as the capacity index, the dependent variable, has a range from 0 to 1 . This two-stage estimation is expressed as follows:

$$
\begin{aligned}
& \text { Innovation }_{i}=\alpha_{0}+\alpha_{1} \text { Capability }_{i}+\alpha_{2} \text { External }_{i}+\alpha_{3} X_{i}+u_{i} \\
& \text { Capability }_{i}=\beta_{0}+\beta_{1} \text { External }_{i}+\alpha_{2} X_{i}+\alpha_{3} Z_{i}+v_{i}
\end{aligned}
$$

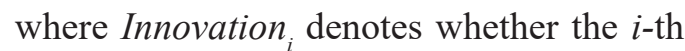
firm achieves product innovation, and it takes zero if it replied "not," while it takes one if it said "yes." Capacity ${ }_{i}$ implies its capacity index, and External indicates the external linkages the $i$-th firm has. External include concretely the 13 sources which were explained in the previous section. $X$ is a firm's characteristics, including "Year of Establishment", "Number of Fulltime Employees (categorical data)" and "Main Business Activities (dummy)". $X$ also includes dummy variables such as Indonesia, Thailand and Hanoi and Ho Chi Minh in Vietnam, while the Philippines is excluded by normalization. $\mathrm{Z}$ indicates consists of instruments, which will be explained later in more detail. 
The procedures (i) and (ii) in Figure 4 correspond to equations (2) and (1), respectively.

\section{B. Estimation Method: Endogeneity and Instruments}

The above estimation is based on "models with dichotomous dependent variables and endogenous regressors". The rationale for this is that if estimating equation (1) alone is adopted by a probit model, then capacity index and the error term have a correlation, since capacity index is an endogenous variable. As a result, estimator $\alpha_{1}$ has a possibly endogenous bias. In order to avoid this, instrumental variables were introduced into the probit model including equation (2) in a reduced form in addition to equation (1). It is also assumed that the error terms of $u$ and $v$ are statistically independent. More precisely, the study assumed that they are independent and identically distributed multi-variates normal for all $i$.

Regarding instruments, $Z$ in equation (2) is an additional instrument which does not influence the dependent variable of product innovation. $Z$ consists of the following nine variables: i) $100 \%$ foreign-owned (MNC), ii) implementing ASEAN-Japan FTA in exports, iii) manufacturer of main production machinery provides training to machine operator, iv) having affiliates in Japan, v) co-development of new capital goods with capital goods producers, vi) increased degree of automation of production process, vii) investment project has been granted government's preferential treatment, viii) IT system for information sharing connected to production development, and ix) installed productive machines made in Japan.

Instruments are selected according to a correlation with a dependent variable and the problem of over-identification. They are different according to these cases. The criterion for this selection is based on a condition such as that they are correlated with the innovation capacity index, instead of a dependent variable. Nevertheless, it is difficult to select instruments to meet this criterion. Table 10 contains the list of instruments selected and the correlation with endogenous variables indicating that correlation coefficients with the capacity index are larger than those with product innovations. For example, list in Table 10 contains "co-development of new capital goods with capital goods producers," which seems to be reasonable, since it promotes internal capacity, but has less of a relationship to product innovation. MNC respondents might be related to the level of internal capacity, but not directly to product innovation. A similar interpretation might show that variables related to Japan also seem to have a higher internal capacity index, but they are not related to innovation directly.

\section{Table 10.}

Correlation Matrix of Endogenous and Instrumental Variables

\begin{tabular}{|c|c|c|c|c|c|}
\hline \multirow{2}{*}{ Instrumental variables } & \multicolumn{5}{|c|}{ Endogenous variables } \\
\hline & (1) & $(2)$ & (3) & (4) & (5) \\
\hline $100 \%$ foreign-owned (MNC) & 0.13 & 0.14 & 0.09 & 0.05 & 0.22 \\
\hline ASEAN-Japan FTA in export & 0.10 & 0.13 & 0.13 & 0.04 & 0.23 \\
\hline $\begin{array}{l}\text { Manufacturer of main production machineries provide training to ma- } \\
\text { chine }\end{array}$ & 0.06 & 0.06 & 0.14 & 0.05 & 0.25 \\
\hline Have affiliates in Japan & -0.01 & 0.03 & 0.00 & 0.06 & 0.23 \\
\hline Co-development of new capital goods with capital goods producers & 0.05 & 0.11 & 0.01 & 0.17 & 0.24 \\
\hline Increased degree of automation of production process & 0.20 & 0.21 & 0.29 & 0.08 & 0.27 \\
\hline Investment project has been granted government's preferential treatment & 0.20 & 0.11 & 0.06 & 0.08 & 0.21 \\
\hline IT system for information sharing connected to development & 0.22 & 0.18 & 0.19 & 0.06 & 0.21 \\
\hline Installed productive machines made in Japan & 0.13 & 0.16 & 0.07 & 0.09 & 0.25 \\
\hline
\end{tabular}

Note: Instruments used in actual estimations are expressed in bold.

(1) Innovation Type 1: Redesigning packaging or significantly changing appearance design

(2) Innovation Type II: Significantly improving existing products

(3) Innovation Type III: New product based on the existing technologies

(4) Innovation Type IV: New product based on new technologies

(5) Internal innovation capacity index 


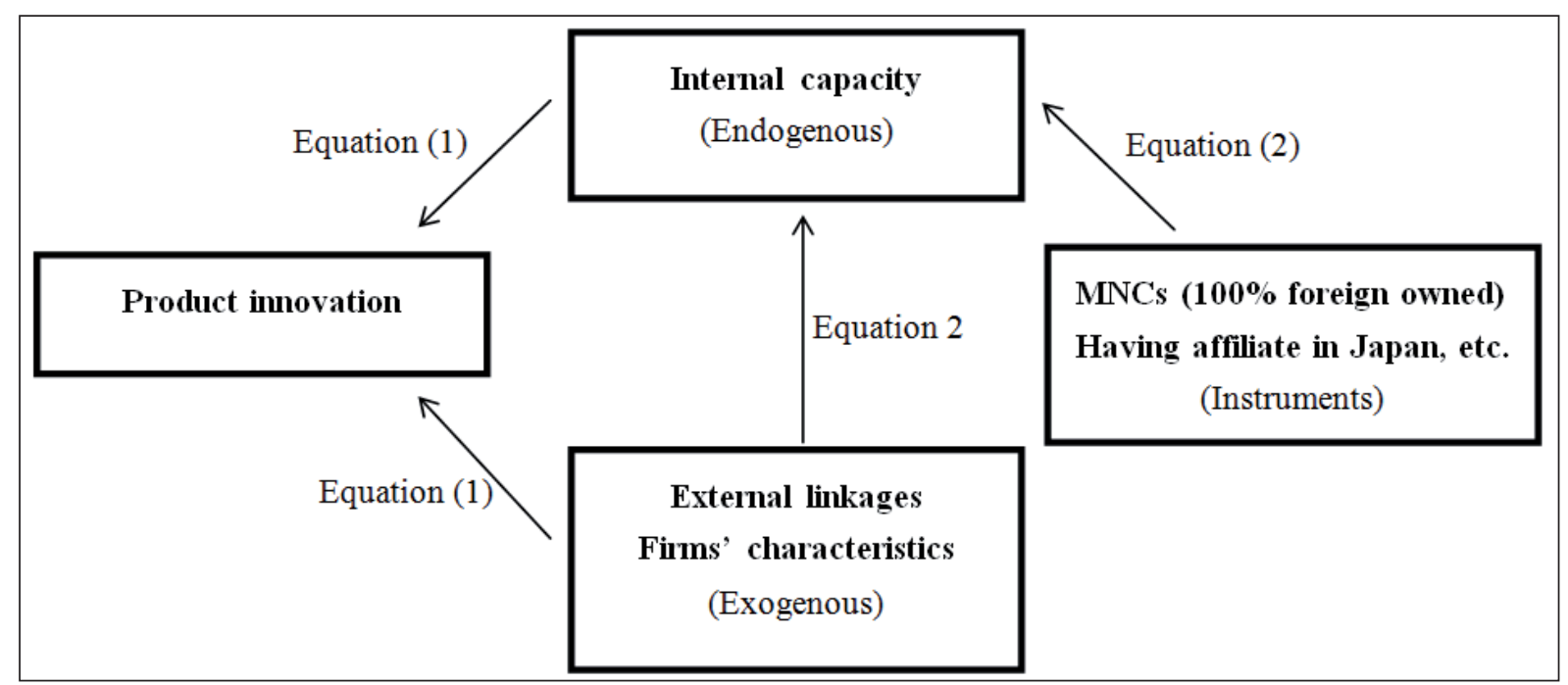

Figure 4. Relationship of Variables and Procedure of Model

Based on the above discussions, the procedure of estimations in this section can be summarized in Figure 4. It should be noted that since Capacity $_{i}$ in equation (2) is already controlled with regard to its endogeneity, the estimated coefficients demonstrate causality from capacity to innovation.

\section{Results of Estimations}

The estimations were conducted for each innovation type, and Tables 11-14 show the results. Equation (1) and (2) were used for estimation contain only one external linkage, and there are 13 models for each external linkage. In each Table, the results of equation (1) are shown in the upper parts of Table, while those of equation (2) are shown in the lower parts.

\section{Causality}

First, the study examined the results of equation (2) shown in Tables 11-14. As for instruments, "100\% foreign-owned (MNC)," "implementing ASEAN-Japan FTA in exports," "manufacturer of main production machinery provides training to machine operator," and "having affiliates in Japan," are utilized as instruments in the models of Innovation type innovation I, II, and III. In the estimation model of innovation type IV, however, since the above instruments did not satisfy the test for over-identifying restrictions, the following instruments, such as " $100 \%$ foreign-owned
(MNC)," "co-development of new capital goods with capital goods producers," "increased degree of automation of production process," "investment project has been granted government's preferential treatment," "IT system for information sharing connected to production development," and "installed productive machines made in Japan," were used. As a result, all of the estimations passed the test for over-identifying restrictions, which confirms that these instruments were suitably selected.

Tables 11-14 show that coefficients of external linkages such as Case 4 (consultant) for innovation type 1, and Case 5 (local customers) for innovation type II, III, and IV were not significant, but for other cases, all instruments were positively significant, implying that these four estimations verified causality. In other words, the study proved causality from internal capacity to product innovation. Accordingly, these two variables were not simply "seemingly correlated."

\section{Verifying Hypotheses}

\section{i) Hypothesis I: From Internal Capacity to Innovation}

Regarding the results of equation (1), all estimations for innovation type I-IV indicated in the upper parts of Tables 11-14, results of equation (1) show that the coefficients of the internal capacity index for all cases are positively significant $(p<0.01)$. Therefore, Hypothesis $\mathbf{I}$ is demonstrated by internal capacity affects the 
probability of achieving product innovation, in which the internal capacity raises the probability of an innovative product.

\section{ii) Hypothesis II: From External Linkages to Internal Capacity}

According to the estimation results of equation (1), the effects of each external linkage on innovation are shown in the lower parts of Tables 11-14. It is only Case $9(\mathrm{MNC} / \mathrm{JV}$ customer located in a foreign country) in innovation type III that is negatively significant coefficients to innovation. In other cases, innovation types, coefficients of external linkages are not significant at all, which demonstrates Hypothesis II. That is, the external linkages do not promote innovation directly.

\section{iii) Hypothesis III: From External Linkages Finally to Innovation}

As mentioned in (i) Causality, Tables 11-14 show that coefficients of external linkages such as Case 4 (consultant) for innovation type 1, and Case 5 (local customers) for innovation type II, III, and IV are not significant. However, the other external linkages for all innovation types have positively significant coefficients. Except these two external linkages, others are positively significant, implying external linkages promote internal capability. In addition, from Hypothesis I, it follows that internal capacity enhances innovation. By adding these two, it can be concluded that external linkages promote innovation indirectly via innovation capacity. This verifies Hypothesis III.

\section{DISCUSSIONS AND CONCLUSION}

This section is aimed to examine closely and elaborate the results obtained by focusing on how external linkages promote internal innovation capability, comparison with previous papers and further research to solve limitations of the paper.

\section{A. Discussions}

\section{i) Conjectures from Instruments}

Tables 11-14 indicate that instruments such as "manufacturer of main production machinery provides training to machine operator," "codevelopment of new capital goods with capital goods producers," "increased degree of automation of production process," and "installed productive machines made in Japan" significantly affect capacity. Some instruments are related to the linkage with Japan, such as "implementing ASEAN-Japan FTA in exports," "having affiliates in Japan," and "installed productive machines made in Japan," which direct us to the importance of Japan as a partner for product innovation in ASEAN countries. In particular, an instrumental variable such as "installed productive machines made in Japan" is utilized only in the model for Innovation type IV, which is the most advanced innovative category of the four kinds of product innovation. A high level of product innovation requires high internal capacity empowered by capital goods and linkages with Japan.

\section{ii) Channels from External Linkages to Innovation Capacity}

As mentioned earlier, all coefficients of external linkages are significant, except Case 4 (Consultant) for Innovation type 1 and Case 5 (local customers) for Innovation type II, III, and IV. Since they are significant at the $1 \%$ level, it is difficult to determine which linkages are important. In comparison with the values of coefficients, Case 2 (Competitor), Case 9 (MNC/JV customers located in a foreign country), and Case 10 (MNC/JV suppliers located in a foreign country) have larger coefficients for all innovation types. The results of in-depth interviews, field research, and Tsuji et al. (2016) expect Case 7 (MNC/JV customers located in country) and Case 8 (MNC/ $\mathrm{JV}$ suppliers located in country) are supposed to have larger effect. Further analysis is required to identify the influential external linkages.

\section{iii) Comparison with other models}

Kesidoua \& Szirmai (2008) analyzed innovation in the Uruguay software industry with the same 2SLS estimation and found that for innovation, local knowledge spillovers are important through labor mobility and non-transaction activities inside the cluster; while the relationship with $\mathrm{MNC/}$ university via spin-off and knowledge flow based on local transactions, do not have an effect on innovation. 
Table 11. Effect of Innovation Capacity and External Linkages to Innovation Type I

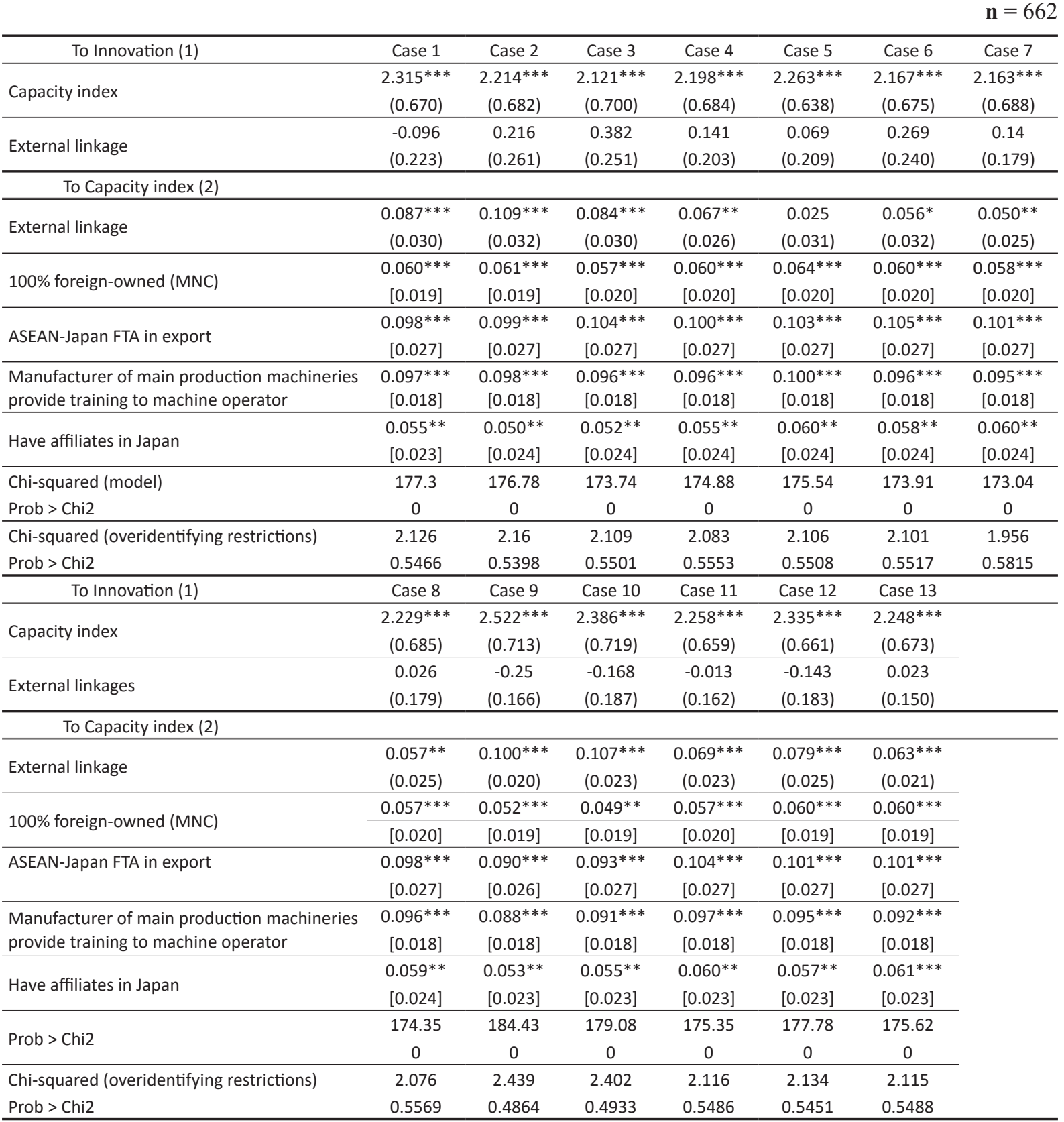

Note 1: Standard errors in brackets. * indicates significance at $10 \%, * *$ significance at $5 \%$, $* * *$ significance at $1 \%$.

Note 2: Case 1: Final consumer, Case 2: Competitor, Case 3: Buyer or trading company, Case 4: Consultant, Case 5: Local customer (100\% local capital), Case 6: Local supplier (100\% local capital), Case 7: MNC/JV customer located in country, Case 8: MNC/JV supplier located in country, Case 9: MNC/JV customer located in a foreign country, Case 10: MNC/JV supplier located in a foreign country, Case 11: Public organization, Case 12: Local business organization, Case 13: University or public research institute.

Note 3: Other control variables are, "Year of establishment," "Number of employees," "Main business activities," and country dummy variables.

Note 4: Instruments are, "100\% foreign-owned (MNC)," “Implementing ASEAN-Japan FTA in exports," "Manufacturer of main production machinery provides training to machine operator," "Having affiliates in Japan," while capacity index is instrumented. 
Table 12.

Effect of Capacity and External Linkages to Innovation Type II

\begin{tabular}{|c|c|c|c|c|c|c|c|}
\hline To Innovation (1) & Case 1 & Case 2 & Case 3 & Case 4 & Case 5 & Case 6 & Case 7 \\
\hline Capacity index & $\begin{array}{c}2.658 * * * \\
(0.647)\end{array}$ & $\begin{array}{c}2.484 * * * \\
(0.670) \\
\end{array}$ & $\begin{array}{c}2.477 * * * \\
(0.676) \\
\end{array}$ & $\begin{array}{c}2.500 * * * \\
(0.667)\end{array}$ & $\begin{array}{c}2.567 * * * \\
(0.622)\end{array}$ & $\begin{array}{c}2.538 * * * \\
(0.649)\end{array}$ & $\begin{array}{c}2.587 * * * \\
(0.654)\end{array}$ \\
\hline External linkage & $\begin{array}{l}-0.202 \\
(0.221) \\
\end{array}$ & $\begin{array}{c}0.326 \\
(0.277) \\
\end{array}$ & $\begin{array}{c}0.251 \\
(0.245) \\
\end{array}$ & $\begin{array}{c}0.148 \\
(0.206) \\
\end{array}$ & $\begin{array}{c}0.03 \\
(0.211) \\
\end{array}$ & $\begin{array}{c}0.094 \\
(0.235) \\
\end{array}$ & $\begin{array}{c}-0.03 \\
(0.175) \\
\end{array}$ \\
\hline \multicolumn{8}{|l|}{ To Capacity index (2) } \\
\hline External linkage & $\begin{array}{c}0.086 * * * \\
(0.030)\end{array}$ & $\begin{array}{c}0.108^{* * *} \\
(0.032)\end{array}$ & $\begin{array}{c}0.084 * * * \\
(0.030)\end{array}$ & $\begin{array}{c}0.067^{* *} \\
(0.026)\end{array}$ & $\begin{array}{c}0.026 \\
(0.031)\end{array}$ & $\begin{array}{l}0.056^{*} \\
(0.032)\end{array}$ & $\begin{array}{c}0.050^{* *} \\
(0.025)\end{array}$ \\
\hline $100 \%$ foreign-owned (MNC) & $\begin{array}{c}0.059 * * * \\
{[0.019]}\end{array}$ & $\begin{array}{c}0.061 * * * \\
{[0.019]}\end{array}$ & $\begin{array}{c}0.057 * * * \\
{[0.020]}\end{array}$ & $\begin{array}{c}0.059 * * * \\
{[0.019]}\end{array}$ & $\begin{array}{c}0.063^{* * *} \\
{[0.019]}\end{array}$ & $\begin{array}{c}0.060 * * * \\
{[0.020]}\end{array}$ & $\begin{array}{c}0.058 * * * \\
{[0.020]}\end{array}$ \\
\hline ASEAN-Japan FTA in export & $\begin{array}{c}0.101 * * * \\
{[0.027]}\end{array}$ & $\begin{array}{c}0.102 * * * \\
{[0.027]}\end{array}$ & $\begin{array}{c}0.107 * * * \\
{[0.027]}\end{array}$ & $\begin{array}{c}0.103^{* * *} \\
{[0.027]}\end{array}$ & $\begin{array}{c}0.106 * * * \\
{[0.027]}\end{array}$ & $\begin{array}{c}0.107^{* * *} \\
{[0.027]}\end{array}$ & $\begin{array}{c}0.103 * * * \\
{[0.027]}\end{array}$ \\
\hline $\begin{array}{l}\text { Manufacturer of main production ma- } \\
\text { chineries provide training to machine } \\
\text { operator }\end{array}$ & $\begin{array}{c}0.093 * * * \\
{[0.018]}\end{array}$ & $\begin{array}{c}0.095^{* * *} \\
{[0.018]}\end{array}$ & $\begin{array}{c}0.093 * * * \\
{[0.018]}\end{array}$ & $\begin{array}{c}0.093 * * * \\
{[0.018]}\end{array}$ & $\begin{array}{c}0.097 * * * \\
{[0.018]}\end{array}$ & $\begin{array}{c}0.093 * * * \\
{[0.018]}\end{array}$ & $\begin{array}{c}0.092^{* * *} \\
{[0.018]}\end{array}$ \\
\hline Have affiliates in Japan & $\begin{array}{c}0.058 * * \\
{[0.023]}\end{array}$ & $\begin{array}{c}0.053 * * \\
{[0.023]}\end{array}$ & $\begin{array}{c}0.055^{* *} \\
{[0.023]}\end{array}$ & $\begin{array}{c}0.058 * * \\
{[0.023]}\end{array}$ & $\begin{array}{c}0.063 * * * \\
{[0.023]}\end{array}$ & $\begin{array}{c}0.061 * * * \\
{[0.023]}\end{array}$ & $\begin{array}{c}0.062 * * * \\
{[0.023]}\end{array}$ \\
\hline Chi-squared (model) & 184.74 & 181.11 & 179.77 & 180.57 & 181.07 & 180.61 & 182.04 \\
\hline Prob > Chi2 & 0 & 0 & 0 & 0 & 0 & 0 & 0 \\
\hline $\begin{array}{l}\text { Chi-squared (overidentifying restric- } \\
\text { tions) }\end{array}$ & 2.819 & 2.802 & 2.844 & 2.768 & 2.793 & 2.866 & 2.761 \\
\hline Prob > Chi2 & 0.4204 & 0.4232 & 0.4162 & 0.4288 & 0.4247 & 0.4128 & 0.43 \\
\hline To Innovation (1) & Case 8 & Case 9 & Case 10 & Case 11 & Case 12 & Case 13 & \\
\hline Capacity index & $\begin{array}{c}2.680 * * * \\
(0.647)\end{array}$ & $\begin{array}{c}2.918^{* * *} \\
(0.677)\end{array}$ & $\begin{array}{c}2.709 * * * \\
(0.697)\end{array}$ & $\begin{array}{c}2.560^{* * *} \\
(0.642)\end{array}$ & $\begin{array}{c}2.631^{* * *} \\
(0.643)\end{array}$ & $\begin{array}{c}2.552^{* * *} \\
(0.657) \\
\end{array}$ & \\
\hline External linkage & $\begin{array}{l}-0.177 \\
(0.174) \\
\end{array}$ & $\begin{array}{c}-0.341 * * \\
(0.163) \\
\end{array}$ & $\begin{array}{l}-0.195 \\
(0.187) \\
\end{array}$ & $\begin{array}{c}0.022 \\
(0.164) \\
\end{array}$ & $\begin{array}{l}-0.127 \\
(0.185) \\
\end{array}$ & $\begin{array}{c}0.048 \\
(0.151) \\
\end{array}$ & \\
\hline \multicolumn{8}{|l|}{ To Capacity index (2) } \\
\hline External linkage & $\begin{array}{l}0.057 * * \\
(0.025)\end{array}$ & $\begin{array}{c}0.100 * * * \\
(0.020)\end{array}$ & $\begin{array}{c}0.107 * * * \\
(0.023)\end{array}$ & $\begin{array}{c}0.070 * * * \\
(0.023)\end{array}$ & $\begin{array}{c}0.079 * * * \\
(0.025)\end{array}$ & $\begin{array}{c}0.064 * * * \\
(0.021) \\
\end{array}$ & \\
\hline $100 \%$ foreign-owned (MNC) & $\begin{array}{c}0.057^{* * *} \\
{[0.020]}\end{array}$ & $\begin{array}{c}0.052^{* * *} \\
{[0.019]}\end{array}$ & $\begin{array}{l}0.049 * * \\
{[0.019]}\end{array}$ & $\begin{array}{c}0.056 * * * \\
{[0.019]}\end{array}$ & $\begin{array}{c}0.060 * * * \\
{[0.019]}\end{array}$ & $\begin{array}{c}0.059 * * * \\
{[0.019]}\end{array}$ & \\
\hline ASEAN-Japan FTA in export & $\begin{array}{c}0.101 * * * \\
{[0.027]}\end{array}$ & $\begin{array}{c}0.094^{* * *} \\
{[0.026]}\end{array}$ & $\begin{array}{c}0.096 * * * \\
{[0.026]}\end{array}$ & $\begin{array}{c}0.107^{* * *} \\
{[0.027]}\end{array}$ & $\begin{array}{c}0.104 * * * \\
{[0.027]}\end{array}$ & $\begin{array}{c}0.104 * * * \\
{[0.027]}\end{array}$ & \\
\hline $\begin{array}{l}\text { Manufacturer of main production ma- } \\
\text { chineries provide training to machine } \\
\text { operator }\end{array}$ & $\begin{array}{c}0.093 * * * \\
{[0.018]}\end{array}$ & $\begin{array}{c}0.084^{* * *} \\
{[0.018]}\end{array}$ & $\begin{array}{c}0.087^{* * *} \\
{[0.018]}\end{array}$ & $\begin{array}{c}0.093 * * * \\
{[0.018]}\end{array}$ & $\begin{array}{c}0.091^{* * *} \\
{[0.018]}\end{array}$ & $\begin{array}{c}0.088^{* * *} \\
{[0.018]}\end{array}$ & \\
\hline Have affiliates in Japan & $\begin{array}{c}0.062 * * * \\
{[0.023]}\end{array}$ & $\begin{array}{c}0.056 * * \\
{[0.023]}\end{array}$ & $\begin{array}{c}0.058 * * \\
{[0.023]}\end{array}$ & $\begin{array}{c}0.063 * * * \\
{[0.023]}\end{array}$ & $\begin{array}{c}0.061 * * * \\
{[0.023]}\end{array}$ & $\begin{array}{c}0.065 * * * \\
{[0.023]}\end{array}$ & \\
\hline Chi-squared (model) & 185.96 & 196.7 & 186.17 & 181.46 & 183.69 & 181.78 & \\
\hline Prob > Chi2 & 0 & 0 & 0 & 0 & 0 & 0 & \\
\hline $\begin{array}{l}\text { Chi-squared (overidentifying restric- } \\
\text { tions) }\end{array}$ & 2.961 & 3.104 & 3.063 & 2.742 & 2.703 & 2.874 & \\
\hline Prob > Chi2 & 0.3976 & 0.3759 & 0.3821 & 0.4331 & 0.4397 & 0.4115 & \\
\hline
\end{tabular}

Notes: see Table 11's notes. 
Table 13.

Effect of Capacity and External Linkages to Innovation Type III

$\mathrm{n}=662$

\begin{tabular}{|c|c|c|c|c|c|c|c|}
\hline To Innovation (1) & Case 1 & Case 2 & Case 3 & Case 4 & Case 5 & Case 6 & Case 7 \\
\hline Capacity index & $\begin{array}{c}2.997 * * * \\
(0.574)\end{array}$ & $\begin{array}{c}2.968^{* * *} \\
(0.576) \\
\end{array}$ & $\begin{array}{c}2.962 * * * \\
(0.580) \\
\end{array}$ & $\begin{array}{c}2.917^{* * *} \\
(0.585) \\
\end{array}$ & $\begin{array}{c}2.917 * * * \\
(0.555) \\
\end{array}$ & $\begin{array}{c}2.923 * * * \\
(0.572) \\
\end{array}$ & $\begin{array}{c}2.888 * * * \\
(0.590)\end{array}$ \\
\hline External linkages & $\begin{array}{c}-0.13 \\
(0.226)\end{array}$ & $\begin{array}{c}0.035 \\
(0.262)\end{array}$ & $\begin{array}{c}0.022 \\
(0.235)\end{array}$ & $\begin{array}{c}0.084 \\
(0.209)\end{array}$ & $\begin{array}{c}0.016 \\
(0.214)\end{array}$ & $\begin{array}{c}0.021 \\
(0.235)\end{array}$ & $\begin{array}{c}0.078 \\
(0.183)\end{array}$ \\
\hline \multicolumn{8}{|l|}{ To Capacity index (2) } \\
\hline External linkage & $\begin{array}{c}0.087 * * * \\
(0.030)\end{array}$ & $\begin{array}{c}0.110^{* * *} \\
(0.032)\end{array}$ & $\begin{array}{c}0.085^{* * * *} \\
(0.030)\end{array}$ & $\begin{array}{c}0.068 * * \\
(0.026)\end{array}$ & $\begin{array}{c}0.024 \\
(0.031) \\
\end{array}$ & $\begin{array}{l}0.056^{*} \\
(0.032) \\
\end{array}$ & $\begin{array}{c}0.050 * * \\
(0.025)\end{array}$ \\
\hline $100 \%$ foreign-owned (MNC) & $\begin{array}{c}0.053 * * * \\
{[0.019]}\end{array}$ & $\begin{array}{c}0.054^{* * *} \\
{[0.019]}\end{array}$ & $\begin{array}{c}0.051 * * * \\
{[0.019]}\end{array}$ & $\begin{array}{c}0.053^{* * *} \\
{[0.019]}\end{array}$ & $\begin{array}{c}0.057 * * * \\
{[0.019]}\end{array}$ & $\begin{array}{c}0.054 * * * \\
{[0.019]}\end{array}$ & $\begin{array}{c}0.052 * * * \\
{[0.019]}\end{array}$ \\
\hline ASEAN-Japan FTA in export & $\begin{array}{c}0.101 * * * \\
{[0.026]}\end{array}$ & $\begin{array}{c}0.101^{* * *} \\
{[0.026]}\end{array}$ & $\begin{array}{c}0.106 * * * \\
{[0.026]}\end{array}$ & $\begin{array}{c}0.103^{* * *} \\
{[0.026]}\end{array}$ & $\begin{array}{c}0.106 * * * \\
{[0.026]}\end{array}$ & $\begin{array}{c}0.107 * * * \\
{[0.026]}\end{array}$ & $\begin{array}{c}0.104 * * * \\
{[0.026]}\end{array}$ \\
\hline $\begin{array}{l}\text { Manufacturer of main production ma- } \\
\text { chineries provide training to machine } \\
\text { operator }\end{array}$ & $\begin{array}{c}0.102 * * * \\
{[0.017]}\end{array}$ & $\begin{array}{c}0.103 * * * \\
{[0.017]}\end{array}$ & $\begin{array}{c}0.101^{* * *} \\
{[0.017]}\end{array}$ & $\begin{array}{c}0.102 * * * \\
{[0.017]}\end{array}$ & $\begin{array}{c}0.106 * * * \\
{[0.017]}\end{array}$ & $\begin{array}{c}0.102 * * * \\
{[0.017]}\end{array}$ & $\begin{array}{c}0.101 * * * \\
{[0.017]}\end{array}$ \\
\hline Have affiliates in Japan & $\begin{array}{c}0.047 * * \\
{[0.023]} \\
\end{array}$ & $\begin{array}{l}0.043^{*} \\
{[0.023]}\end{array}$ & $\begin{array}{l}0.045^{*} \\
{[0.023]}\end{array}$ & $\begin{array}{c}0.048 * * \\
{[0.023]} \\
\end{array}$ & $\begin{array}{c}0.052 * * \\
{[0.023]}\end{array}$ & $\begin{array}{c}0.050 * * \\
{[0.023]}\end{array}$ & $\begin{array}{c}0.052 * * \\
{[0.023]}\end{array}$ \\
\hline Chi-squared (model) & 144.98 & 145.72 & 144.58 & 142.8 & 140.85 & 141.7 & 140.48 \\
\hline Prob > Chi2 & 0 & 0 & 0 & 0 & 0 & 0 & 0 \\
\hline $\begin{array}{l}\text { Chi-squared (overidentifying restric- } \\
\text { tions) }\end{array}$ & 2.948 & 2.986 & 2.984 & 3.03 & 3.043 & 3.048 & 3.012 \\
\hline Prob > Chi2 & 0.3996 & 0.3938 & 0.3941 & 0.3871 & 0.385 & 0.3842 & 0.3898 \\
\hline To Innovation (1) & Case 8 & Case 9 & Case 10 & Case 11 & Case 12 & Case 13 & \\
\hline Capacity index & $\begin{array}{c}2.976 * * * \\
(0.580) \\
\end{array}$ & $\begin{array}{c}3.389 * * * \\
(0.567) \\
\end{array}$ & $\begin{array}{c}3.104 * * * \\
(0.604) \\
\end{array}$ & $\begin{array}{c}2.967^{* * *} \\
(0.564) \\
\end{array}$ & $\begin{array}{c}3.028 * * * \\
(0.565) \\
\end{array}$ & $\begin{array}{c}2.990 * * * \\
(0.575) \\
\end{array}$ & \\
\hline External linkage & $\begin{array}{l}-0.083 \\
(0.180) \\
\end{array}$ & $\begin{array}{c}-0.470 * * * \\
(0.151) \\
\end{array}$ & $\begin{array}{r}-0.206 \\
(0.185) \\
\end{array}$ & $\begin{array}{l}-0.118 \\
(0.161) \\
\end{array}$ & $\begin{array}{l}-0.266 \\
(0.180) \\
\end{array}$ & $\begin{array}{l}-0.152 \\
(0.145) \\
\end{array}$ & \\
\hline \multicolumn{8}{|l|}{ To Capacity index (2) } \\
\hline External linkages & $\begin{array}{c}0.057 * * \\
(0.025)\end{array}$ & $\begin{array}{c}0.100 * * * \\
(0.020)\end{array}$ & $\begin{array}{c}0.108 * * * \\
(0.023)\end{array}$ & $\begin{array}{c}0.070 * * * \\
(0.023)\end{array}$ & $\begin{array}{c}0.079 * * * \\
(0.025)\end{array}$ & $\begin{array}{c}0.062 * * * \\
(0.021)\end{array}$ & \\
\hline $100 \%$ foreign-owned (MNC) & $\begin{array}{c}0.051 * * * \\
{[0.019]}\end{array}$ & $\begin{array}{c}0.045^{* *} \\
{[0.018]}\end{array}$ & $\begin{array}{c}0.042 * * \\
{[0.019]}\end{array}$ & $\begin{array}{c}0.050 * * * \\
{[0.019]}\end{array}$ & $\begin{array}{c}0.053 * * * \\
{[0.019]}\end{array}$ & $\begin{array}{c}0.053 * * * \\
{[0.019]}\end{array}$ & \\
\hline ASEAN-Japan FTA in export & $\begin{array}{c}0.101^{* * *} \\
{[0.026]}\end{array}$ & $\begin{array}{c}0.093 * * * \\
{[0.025]}\end{array}$ & $\begin{array}{c}0.096 * * * \\
{[0.026]}\end{array}$ & $\begin{array}{c}0.107^{* * *} \\
{[0.026]}\end{array}$ & $\begin{array}{c}0.104 * * * \\
{[0.026]}\end{array}$ & $\begin{array}{c}0.104 * * * \\
{[0.026]}\end{array}$ & \\
\hline $\begin{array}{l}\text { Manufacturer of main production ma- } \\
\text { chineries provide training to machine } \\
\text { operator }\end{array}$ & $\begin{array}{c}0.102 * * * \\
{[0.017]}\end{array}$ & $\begin{array}{c}0.094 * * * \\
{[0.017]}\end{array}$ & $\begin{array}{c}0.096 * * * \\
{[0.017]}\end{array}$ & $\begin{array}{c}0.102 * * * \\
{[0.017]}\end{array}$ & $\begin{array}{c}0.101^{* * *} \\
{[0.017]}\end{array}$ & $\begin{array}{c}0.099 * * * \\
{[0.017]}\end{array}$ & \\
\hline Have affiliates in Japan & $\begin{array}{c}0.052 * * \\
{[0.023]} \\
\end{array}$ & $\begin{array}{l}0.044^{*} \\
{[0.022]}\end{array}$ & $\begin{array}{c}0.047 * * \\
{[0.023]} \\
\end{array}$ & $\begin{array}{c}0.052 * * \\
{[0.023]} \\
\end{array}$ & $\begin{array}{c}0.050 * * \\
{[0.023]} \\
\end{array}$ & $\begin{array}{c}0.053^{* *} \\
{[0.023]} \\
\end{array}$ & \\
\hline Chi-squared (model) & 143.67 & 167.83 & 150.2 & 142.82 & 145.9 & 143.51 & \\
\hline Prob > Chi2 & 0 & 0 & 0 & 0 & 0 & 0 & \\
\hline $\begin{array}{l}\text { Chi-squared (overidentifying restric- } \\
\text { tions) }\end{array}$ & 3.105 & 3.163 & 2.968 & 3.051 & 3.183 & 3.375 & \\
\hline Prob > Chi2 & 0.3757 & 0.3672 & 0.3967 & 0.3838 & 0.3643 & 0.3374 & \\
\hline
\end{tabular}

Notes: see Table 11's notes. 
Table 14.

Effect of Capacity Index and External Linkages to Innovation Type IV

\begin{tabular}{|c|c|c|c|c|c|c|c|}
\hline To Innovation (1) & Case 1 & Case 2 & Case 3 & Case 4 & Case 5 & Case 6 & Case 7 \\
\hline Capacity index & $\begin{array}{c}2.372 * * * \\
(0.697) \\
\end{array}$ & $\begin{array}{c}2.368 * * * \\
(0.689)\end{array}$ & $\begin{array}{c}2.404^{* * *} \\
(0.695) \\
\end{array}$ & $\begin{array}{c}2.391 * * * \\
(0.682) \\
\end{array}$ & $\begin{array}{c}2.409 * * * \\
(0.657)\end{array}$ & $\begin{array}{c}2.432 * * * \\
(0.668) \\
\end{array}$ & $\begin{array}{c}2.483 * * * \\
(0.682)\end{array}$ \\
\hline External linkages & $\begin{array}{c}0.169 \\
(0.289)\end{array}$ & $\begin{array}{c}0.259 \\
(0.312)\end{array}$ & $\begin{array}{c}0.065 \\
(0.271)\end{array}$ & $\begin{array}{c}0.082 \\
(0.234)\end{array}$ & $\begin{array}{l}-0.026 \\
(0.239)\end{array}$ & $\begin{array}{l}-0.048 \\
(0.260)\end{array}$ & $\begin{array}{l}-0.098 \\
(0.200)\end{array}$ \\
\hline \multicolumn{8}{|l|}{ To Capacity index (2) } \\
\hline External linkage & $\begin{array}{c}0.080 * * * \\
(0.029)\end{array}$ & $\begin{array}{c}0.103 * * * \\
(0.031)\end{array}$ & $\begin{array}{l}0.076 * * \\
(0.030)\end{array}$ & $\begin{array}{c}0.073 * * * \\
(0.026)\end{array}$ & $\begin{array}{c}0.03 \\
(0.030) \\
\end{array}$ & $\begin{array}{c}0.062 * * \\
(0.031) \\
\end{array}$ & $\begin{array}{c}0.036 \\
(0.025) \\
\end{array}$ \\
\hline $100 \%$ foreign-owned (MNC) & $\begin{array}{c}0.055^{* * *} \\
{[0.019]}\end{array}$ & $\begin{array}{c}0.055^{* * *} \\
{[0.019]}\end{array}$ & $\begin{array}{c}0.053^{* * *} \\
{[0.019]}\end{array}$ & $\begin{array}{c}0.054 * * * \\
{[0.019]}\end{array}$ & $\begin{array}{c}0.059 * * * \\
{[0.019]}\end{array}$ & $\begin{array}{c}0.055^{* * *} \\
{[0.019]}\end{array}$ & $\begin{array}{c}0.055^{* * *} \\
{[0.019]}\end{array}$ \\
\hline $\begin{array}{l}\text { Co-development of new capital goods } \\
\text { with capital goods producers }\end{array}$ & $\begin{array}{c}0.061^{* * * *} \\
{[0.018]}\end{array}$ & $\begin{array}{c}0.061^{* * *} \\
{[0.018]}\end{array}$ & $\begin{array}{c}0.062 * * * \\
{[0.018]}\end{array}$ & $\begin{array}{c}0.059 * * * \\
{[0.018]}\end{array}$ & $\begin{array}{c}0.062 * * * \\
{[0.018]}\end{array}$ & $\begin{array}{c}0.061^{* * *} \\
{[0.018]}\end{array}$ & $\begin{array}{c}0.060 * * * \\
{[0.018]}\end{array}$ \\
\hline $\begin{array}{l}\text { Increased degree of automation of pro- } \\
\text { duction process }\end{array}$ & $\begin{array}{c}0.055^{* * *} \\
{[0.018]}\end{array}$ & $\begin{array}{c}0.053^{* * *} \\
{[0.018]}\end{array}$ & $\begin{array}{c}0.055^{* * *} \\
{[0.018]}\end{array}$ & $\begin{array}{c}0.056 * * * \\
{[0.018]}\end{array}$ & $\begin{array}{c}0.059 * * * \\
{[0.018]}\end{array}$ & $\begin{array}{c}0.058 * * * \\
{[0.018]}\end{array}$ & $\begin{array}{c}0.056 * * * \\
{[0.018]}\end{array}$ \\
\hline $\begin{array}{l}\text { Investment project has been granted } \\
\text { government's preferential treatment }\end{array}$ & $\begin{array}{c}0.062 * * * \\
{[0.021]}\end{array}$ & $\begin{array}{c}0.063 * * * \\
{[0.021]}\end{array}$ & $\begin{array}{c}0.063^{* * *} \\
{[0.021]}\end{array}$ & $\begin{array}{c}0.067 * * * \\
{[0.021]}\end{array}$ & $\begin{array}{c}0.064 * * * \\
{[0.021]}\end{array}$ & $\begin{array}{c}0.064 * * * \\
{[0.021]}\end{array}$ & $\begin{array}{c}0.064 * * * \\
{[0.021]}\end{array}$ \\
\hline $\begin{array}{l}\text { IT system for information sharing con- } \\
\text { nected to development }\end{array}$ & $\begin{array}{c}0.080 * * * \\
{[0.022]}\end{array}$ & $\begin{array}{c}0.082 * * * \\
{[0.022]}\end{array}$ & $\begin{array}{c}0.080 * * * \\
{[0.022]}\end{array}$ & $\begin{array}{c}0.080 * * * \\
{[0.022]}\end{array}$ & $\begin{array}{c}0.084 * * * \\
{[0.022]}\end{array}$ & $\begin{array}{c}0.081^{* * *} \\
{[0.022]}\end{array}$ & $\begin{array}{c}0.082 * * * \\
{[0.022]}\end{array}$ \\
\hline $\begin{array}{l}\text { Installed productive machines made in } \\
\text { Japan }\end{array}$ & $\begin{array}{c}0.068 * * * \\
{[0.020]}\end{array}$ & $\begin{array}{c}0.066 * * * \\
{[0.020]}\end{array}$ & $\begin{array}{c}0.067^{* * *} \\
{[0.020]}\end{array}$ & $\begin{array}{c}0.070 * * * \\
{[0.020]}\end{array}$ & $\begin{array}{c}0.071 * * * \\
{[0.020]}\end{array}$ & $\begin{array}{c}0.070 * * * \\
{[0.020]}\end{array}$ & $\begin{array}{c}0.069 * * * \\
{[0.020]}\end{array}$ \\
\hline Chi-squared (model) & 42.67 & 44.3 & 42.59 & 42.54 & 41.3 & 41.71 & 42.02 \\
\hline Prob > Chi2 & 0.011 & 0.007 & 0.011 & 0.011 & 0.015 & 0.014 & 0.013 \\
\hline $\begin{array}{l}\text { Chi-squared (over identifying restric- } \\
\text { tions) }\end{array}$ & 5.52 & 5.56 & 5.575 & 5.425 & 5.516 & 5.457 & 5.618 \\
\hline Prob > Chi2 & 0.3557 & 0.3514 & 0.3498 & 0.3662 & 0.3562 & 0.3627 & 0.3451 \\
\hline To Innovation (1) & Case 8 & Case 9 & Case 10 & Case 11 & Case 12 & Case 13 & \\
\hline Capacity index & $\begin{array}{c}2.480 * * * \\
(0.685) \\
\end{array}$ & $\begin{array}{c}2.568 * * * \\
(0.739) \\
\end{array}$ & $\begin{array}{c}2.377^{* * *} \\
(0.754)\end{array}$ & $\begin{array}{c}2.457^{* * *} \\
(0.665) \\
\end{array}$ & $\begin{array}{c}2.464 * * * \\
(0.676) \\
\end{array}$ & $\begin{array}{c}2.522^{* * *} \\
(0.666)\end{array}$ & \\
\hline External linkage & $\begin{array}{c}-0.099 \\
(0.206) \\
\end{array}$ & $\begin{array}{l}-0.191 \\
(0.192) \\
\end{array}$ & $\begin{array}{c}0.07 \\
(0.228) \\
\end{array}$ & $\begin{array}{c}0.019 \\
(0.191) \\
\end{array}$ & $\begin{array}{c}-0.133 \\
(0.210) \\
\end{array}$ & $\begin{array}{c}-0.242 \\
(0.163) \\
\end{array}$ & \\
\hline \multicolumn{8}{|l|}{ To Capacity index (2) } \\
\hline External linkage & $\begin{array}{l}0.047^{*} \\
(0.024) \\
\end{array}$ & $\begin{array}{c}0.089 * * * \\
(0.020)\end{array}$ & $\begin{array}{c}0.090 * * * \\
(0.023)\end{array}$ & $\begin{array}{c}0.072 * * * \\
(0.022)\end{array}$ & $\begin{array}{c}0.077^{* * *} \\
(0.025)\end{array}$ & $\begin{array}{c}0.067^{* * *} \\
(0.020) \\
\end{array}$ & \\
\hline $100 \%$ foreign-owned (MNC) & $\begin{array}{c}0.053 * * * \\
0.019]\end{array}$ & $\begin{array}{c}0.047^{* *} \\
{[0.019]}\end{array}$ & $\begin{array}{c}0.045^{* *} \\
0.020]\end{array}$ & $\begin{array}{c}0.052^{* * *} \\
0.019]\end{array}$ & $\begin{array}{c}0.055^{* * *} \\
{[0.019]}\end{array}$ & $\begin{array}{c}0.055^{* * *} \\
{[0.019]}\end{array}$ & \\
\hline $\begin{array}{l}\text { Co-development of new capital goods } \\
\text { with capital goods producers }\end{array}$ & $\begin{array}{c}0.059 * * * \\
{[0.018]}\end{array}$ & $\begin{array}{c}0.049 * * * \\
{[0.018]}\end{array}$ & $\begin{array}{c}0.053 * * * \\
{[0.018]}\end{array}$ & $\begin{array}{c}0.063^{* * *} \\
{[0.018]}\end{array}$ & $\begin{array}{c}0.059 * * * \\
{[0.018]}\end{array}$ & $\begin{array}{c}0.062^{* * *} \\
{[0.018]}\end{array}$ & \\
\hline $\begin{array}{l}\text { Increased degree of automation of pro- } \\
\text { duction process }\end{array}$ & $\begin{array}{c}0.056 * * * \\
{[0.018]}\end{array}$ & $\begin{array}{c}0.056 * * * \\
{[0.018]}\end{array}$ & $\begin{array}{c}0.051^{* * *} \\
{[0.018]}\end{array}$ & $\begin{array}{c}0.057 * * * \\
{[0.018]}\end{array}$ & $\begin{array}{c}0.056 * * * \\
{[0.018]}\end{array}$ & $\begin{array}{c}0.056 * * * \\
{[0.018]}\end{array}$ & \\
\hline $\begin{array}{l}\text { Investment project has been granted } \\
\text { government's preferential treatment }\end{array}$ & $\begin{array}{c}0.064 * * * \\
{[0.021]}\end{array}$ & $\begin{array}{c}0.059 * * * \\
{[0.021]}\end{array}$ & $\begin{array}{c}0.065 * * * \\
{[0.021]}\end{array}$ & $\begin{array}{c}0.067 * * * \\
{[0.021]}\end{array}$ & $\begin{array}{c}0.065 * * * \\
{[0.021]}\end{array}$ & $\begin{array}{c}0.067^{* * *} \\
{[0.021]}\end{array}$ & \\
\hline $\begin{array}{l}\text { IT system for information sharing con- } \\
\text { nected to development }\end{array}$ & $\begin{array}{c}0.082 * * * \\
{[0.022]}\end{array}$ & $\begin{array}{c}0.079 * * * \\
{[0.022]}\end{array}$ & $\begin{array}{c}0.079 * * * \\
{[0.022]}\end{array}$ & $\begin{array}{c}0.077^{* * *} \\
{[0.022]}\end{array}$ & $\begin{array}{c}0.080 * * * \\
{[0.022]}\end{array}$ & $\begin{array}{c}0.077^{* * *} \\
{[0.022]}\end{array}$ & \\
\hline $\begin{array}{l}\text { Installed productive machines made in } \\
\text { Japan }\end{array}$ & $\begin{array}{c}0.068 * * * \\
{[0.020]}\end{array}$ & $\begin{array}{c}0.066 * * * \\
{[0.020]}\end{array}$ & $\begin{array}{c}0.064 * * * \\
{[0.020]}\end{array}$ & $\begin{array}{c}0.071 * * * \\
{[0.020]}\end{array}$ & $\begin{array}{c}0.070 * * * \\
{[0.020]}\end{array}$ & $\begin{array}{c}0.068 * * * \\
{[0.020]}\end{array}$ & \\
\hline $\begin{array}{l}\text { Chi-squared (model) } \\
\text { Prob }>\text { Chi2 }\end{array}$ & $\begin{array}{l}41.98 \\
0.013\end{array}$ & $\begin{array}{l}41.95 \\
0.013\end{array}$ & $\begin{array}{l}42.72 \\
0.011\end{array}$ & $\begin{array}{l}43.29 \\
0.009\end{array}$ & $\begin{array}{l}41.75 \\
0.014\end{array}$ & $\begin{array}{l}42.65 \\
0.011\end{array}$ & \\
\hline $\begin{array}{l}\text { Chi-squared (over identifying restric- } \\
\text { tions) }\end{array}$ & 5.575 & 6.116 & 5.374 & 5.558 & 5.519 & 5.299 & \\
\hline Prob > Chi2 & 0.3498 & 0.2951 & 0.372 & 0.3516 & 0.3559 & 0.3805 & \\
\hline
\end{tabular}

Note 1, 2 and 3: see Table 11's notes.

Note 4: Instruments are, "100\% foreign-owned (MNC)," "Co-development of new capital goods with capital goods producers," "Increased degree of automation of production process," "Investment project has been granted government's preferential treatment," "IT system for information sharing connected to development," "Installed productive machines made in Japan," while capacity index is instrumented. 
Liao et al. (2010) takes innovation capability as "the performance of the enterprise going through various types of innovation to achieve an overall improvement of its innovation capability," whereas absorptive capacity is defined as "the ratio of $R \& D$ expenditure and sales volume as the measure." They did not provide concrete definition of innovation capability. Although the definition of absorptive capacity is a simple measure, it is strengthened by its supporting elements, such as links between firm and the surrounding environment, the level of knowledge and experience, the diversity of knowledge structure, and the strategic posture for measuring absorptive capacity. By using SEM, they showed the causality from absorptive capacity to knowledge acquisition and to innovation capability. However, their issue is related to the definition of absorptive capacity and innovation capability, since these two concepts are mutually overlapped.

Tsuji et al. (2016) analyzed the role of external linkages to innovation by using SEM. Their conclusion of the effects of external linkages to innovation is similar to this paper. Local SMEs connect to MNCs via the human network of top management who owned experiences working in MNCs. This promotes SMEs' learning process via cross-functional teams or QC, which then enhance innovation. However, MNCs affect innovation via learning process indirectly.

Shigeno, Matsuzaki, and Tsuji, (2018) also demonstrates the causality from external linkages to innovation via internal innovation capability by using SEM, which focuses more on the causality among the individual variables of internal innovation capability such as ICT use, the technological level (the number of patents obtained), and R\&D. The causality it showed is external linkages $\rightarrow$ $\mathrm{ICT} \rightarrow$ technology $\rightarrow \mathrm{R} \& \mathrm{D}$. It is quite interesting that ICT is the first among internal innovation capability, namely local SEMs required to elevate ICT capability to connect to MNCs.

Most of papers discussing the causality employ SEM as an analytical method, as far as we know, since there are various types of software for SEM analysis. The instrumental variable method, on the other hand, is considered as one of the most rigorous empirical research methods to analyze endogeneity. In this sense, this paper has some merits.

\section{B. Concluding Remarks}

According to the above results, this paper verifies the existence of a cumulative process between internal capacity and external linkages. Internal capacity itself directly enhances product innovation, while external linkages promote product innovation indirectly via an enhancement of internal capacity. In this sense, internal capacity is the core of innovation, but it is not necessarily promoted without supplementary external linkages. These results are clear and simple, and as a matter of fact, these are consistent with the reality. This is due to construction of internal innovation capacity index by AHP.

This study, however, owns some limitations which need to be addressed with future analysis. Those are as follows: (i) this paper identify variables to affect internal innovation capability and innovation, and shows causality among them, such as how these variables related with each other, namely how external linkages promotes internal innovation capability, or who absorb information from MNCs. For the latter, Tsuji et al. (2016) identified: i) top management of SMEs who owns working experiences in MNCs; ii) further studies have to focus on transforming information to knowledge, bridging the technology and market, combining basic and applied R\&D, and nurturing human resources to contribute to these; and iii) to make use of this study tho design policy for promoting innovation in ASEAN economies. In addition to policies to promote innovation in SMEs, how these results are utilized for designing national innovation initiatives.

\section{REFERENCES}

Barney, J. (1991). Firm resources and sustained competitive advantage. Journal of Management, 17, 99-120.

Chesbrough, H. W. (2003). Open innovation: The new imperative for creating and profiting from technology. Boston: Harvard Business School Press. 
Chesbrough, H. W. (2006a). Open innovation: A new paradigm for understanding industrial innovation. In H. W. Chesbrough, W. Vanhaverbeke, \& J. West (Eds.) Open innovation researching a new paradigm. Oxford: Oxford University Press.

Chesbrough, H. W. (2006b). Open business model: How to thrive in the new innovation landscape. Boston: Harvard Business School Press.

Cohen, W. M., \& Levinthal D. A. (1990). Absorptive capacity: A new perspective on learning and innovation. Administrative Science Quarterly, 35(1), 128-152.

Colin, C. (2006). Absorptive capacity, knowledge management and innovation in entrepreneurial small firms. International Journal of Entrepreneurial Behaviour \& Research, 12(6), 345-360.

Christensen, C. M., \& Kaufman, S. P. (2009). Assessing your organization's capabilities: Resource, process and priorities. In R. A. Burgelman, C. M. Christensen, \& S. C. Wheelwright (Eds.), Strategic management of technology and innovation, 5th ed. (153-164). Boston: McGraw-Hill.

Fosfuri, A., \& Tribo, J. A. (2008). Exploring the antecedents of potential absorptive capacity and its impact on innovation performance. Omega, 36(2), 173-187.

Idota, H., Ogawa, M., Bunno, T., \& Tsuji, M. (2012). An empirical analysis of organizational innovation generated by ICT in Japanese SMEs. In S. Allegrezza \& S. Dubrocard (Eds.), Internet econometrics (259-287). Hampshire: Macmillan.

Kesidoua, E. \& Szirmai, A. (2008). Local knowledge spillovers, innovation and export performance in developing countries: Empirical evidence from the Uruguay software cluster. The European Journal of Development Research, 20(2), 281-298.

Lawson, B., \& Samson, D. (2001). Developing innovation capacity in organisations: A dynamic capabilities approach. International Journal of Innovation Management, 5(3), 377-400.

Liao, S., Wu, C., Hu, D., \& Tsui, K. (2010). Relationships between knowledge acquisition, absorptive capacity and innovation capacity: An empirical study of Taiwan's knowledge intensive industries. Journal of Information Science, 36(1), 19-35.

Lim, J.-H. Stratopoulos, T. C., \& Wirjanto, T. S. (2011). Path dependence of dynamic information technology capacity: An empirical investigation. Journal of Management Information Systems, 28(3), 45-84.
Nieto, M., \& Pilar, Q. (2005). Absorptive capacity, technological opportunity, knowledge spillovers, and innovative effort. Technovation, 25(10), 1141-1157.

Ogawa, M., Idota, H., Bunno, T., \& Tsuji, M. (2009). Indices of the diffusion of information technology among japanese small-and medium-sized enterprises: An AHP approach. Paper presented at Proceedings of the ISAHP2009, Pittsburgh, Pennsylvania, USA.

Saaty, T. L. (1986a). The analytic hierarchy process: Planning, priority setting, resource allocation. New York: McGraw-Hill.

Saaty, T. L. (1986b). Absolute and relative measurement with the AHP: The most livable cities in the United States. Socio-Economic Planning Sciences, 20(6), 327-331.

Shigeno, H., Matsuzaki, T., \& Tsuji, M. (2018). Internal innovation capability and ICT use in the innovation process from the view of connectivity in Japanese SMEs. Journal of STI Management and Policy, 3(1), 35-50.

Stock, G., Greis, N., \& Fischer, W. (2001). Absorptive capacity and new product development. Journal of High Technology Management Research, 12(1), 77-91.

Tsuji, M. Miyahara, S. \& Ueki, Y. (2008). Consolidated multi-country analysis of industrial agglomeration, upgrading and innovation. Paper presented at Proceedings of EAEA 2008, Manila, Philippines.

Tsuji, M., Akematsu, Y., Ueki, Y., \& Idota, H. (2012). Empirical study of internal innovation capacity in ASEAN economies. Paper presented at Proceedings of EAEA 2012, Singapore.

Tsuji, M., Idota, H., Ueki, Y., Shigeno, H., \& Bunno, T. (2016). Connectivity in the technology transfer process among local ASEAN firms. Contemporary Economics, 10(3), 193-203.

Tsuji, M., Idota, H., Ueki, Y., \& Bunno, T. (2017). Innovation process of natural resource-based firms in four ASEAN economies: A SEM approach. Journal of STI Policy and Management, 2(1), 1-14.

Tsuji, M., Minetaki, K., Akematsu, Y. \& Ueki, Y. (2011) Empirical study of the formation of internal innovation capability and external linkages in ASEAN economies. Paper presented at Proceedings of Globelics 2011, Buenos Aires, Argentina.

van den Bosch, F. A. J., Volberda, H. W., \& Boer, M. D. (1999). Coevolution of firm absorptive capacity and knowledge environment: Organizational forms and combinative capabilities. Organization Science, 10(5), 551-568. 
Yang, J., Rui, M., \& Wang, J. (2006). Enhancing the firm's innovation capability through knowledge management: A study of high technology firms in China. International Journal of Technology Management, 36(4), 305-317.
Zahra, H., \& George, G. (2002). Absorptive capacity: A review, reconceptualization, and extension. Academy of Management Review, 27(2), 185-203. 